\title{
Cochrane
}

Library

Cochrane Database of Systematic Reviews

\section{Policies for replacing long-term indwelling urinary catheters in adults (Review)}

Cooper FPM, Alexander CE, Sinha S, Omar MI

Cooper FPM, Alexander CE, Sinha S, Omar MI.

Policies for replacing long-term indwelling urinary catheters in adults.

Cochrane Database of Systematic Reviews 2016, Issue 7. Art. No.: CD011115.

DOI: 10.1002/14651858.CD011115.pub2.

www.cochranelibrary.com 
TABLE OF CONTENTS

HEADER 1

ABSTRACT

PLAIN LANGUAGE SUMMARY

SUMMARY OF FINDINGS

BACKGROUND

OBJECTIVES

METHODS

RESULTS

Figure 1.

Figure 2.

Figure 3.

DISCUSSION

AUTHORS' CONCLUSIONS

ACKNOWLEDGEMENTS

REFERENCES

CHARACTERISTICS OF STUDIES

DATA AND ANALYSES

Analysis 1.1. Comparison 1 Monthly \& PRN (as needed) catheter replacement versus PRN (as needed) catheter replacement, Outcome 1 Symptomatic CAUTI (up to 6 months after replacement).

Analysis 2.1. Comparison 2 Antibiotics at time of replacement versus no antibiotics at time of replacement, Outcome 1 Positive urine culture.

Analysis 2.2. Comparison 2 Antibiotics at time of replacement versus no antibiotics at time of replacement, Outcome 2 Infection.

Analysis 2.3. Comparison 2 Antibiotics at time of replacement versus no antibiotics at time of replacement, Outcome 3 Bacteraemia.

Analysis 2.4. Comparison 2 Antibiotics at time of replacement versus no antibiotics at time of replacement, Outcome 4 Death. .

Analysis 3.1. Comparison 3 Sterile water versus $0.05 \%$ chlorohexidine gluconate for periurethral cleansing during replacement, Outcome 1 Symptomatic CAUTI (up to 14 days after repacement).

Analysis 3.2. Comparison 3 Sterile water versus $0.05 \%$ chlorohexidine gluconate for periurethral cleansing during replacement, Outcome 2 Asymptomatic bacteruria (as defined by positive urine culture).

APPENDICES

CONTRIBUTIONS OF AUTHORS

DECLARATIONS OF INTEREST

SOURCES OF SUPPORT

DIFFERENCES BETWEEN PROTOCOL AND REVIEW

INDEX TERMS 
[Intervention Review]

\section{Policies for replacing long-term indwelling urinary catheters in adults}

Fergus PM Cooper ${ }^{1}$, Cameron Edwin Alexander ${ }^{1}$, Sanjay Sinha², Muhammad Imran Omar ${ }^{1}$

${ }^{1}$ Academic Urology Unit, University of Aberdeen, Aberdeen, UK. ${ }^{2}$ Apollo Hospital, Hyderabad, India

Contact address: Fergus PM Cooper, Academic Urology Unit, University of Aberdeen, Health Sciences Building, Foresterhill, Aberdeen, AB25 2ZD, UK. fergus_cooper_1992@hotmail.com.

Editorial group: Cochrane Incontinence Group.

Publication status and date: New, published in Issue 7, 2016.

Citation: Cooper FPM, Alexander CE, Sinha S, Omar MI. Policies for replacing long-term indwelling urinary catheters in adults. Cochrane Database of Systematic Reviews 2016, Issue 7. Art. No.: CD011115. DOI: 10.1002/14651858.CD011115.pub2.

Copyright @ 2016 The Cochrane Collaboration. Published by John Wiley \& Sons, Ltd.

\section{A B S T R A C T}

\section{Background}

Long-term indwelling catheters are used commonly in people with lower urinary tract problems in home, hospital and specialised healthcare settings. There are many potential complications and adverse effects associated with long-term catheter use. The effect of healthcare policies related to the replacement of long-term urinary catheters on patient outcomes is unclear.

\section{Objectives}

To determine the effectiveness of different policies for replacing long-term indwelling urinary catheters in adults.

\section{Search methods}

We searched the Cochrane Incontinence Specialised Trials Register, which contains trials identified from the Cochrane Central Register of Controlled Trials (CENTRAL), MEDLINE, MEDLINE In-Process, MEDLINE Epub Ahead of Print, CINAHL, ClinicalTrials.gov, WHO ICTRP and handsearching of journals and conference proceedings (searched 19 May 2016), and the reference lists of relevant articles.

\section{Selection criteria}

All randomised controlled trials investigating policies for replacing long-term indwelling urinary catheters in adults were included.

\section{Data collection and analysis}

At least two review authors independently performed data extraction and assessed risk of bias of all the included trials. Quality of evidence was assessed by adopting the GRADE approach. Any discrepancies were resolved by discussion between the review authors or an independent arbitrator. We contacted the authors of included trials to seek clarification where required.

\section{Main results}

Three trials met the inclusion criteria, with a total of 107 participants in three different health-care settings: A USA veterans administration nursing home; a geriatric centre in Israel; and a community nursing service in Hong Kong. Data were available for three of the pre-stated comparisons. Priefer and colleagues evaluated different time intervals between catheter replacement $(n=17)$; Firestein and colleagues evaluated the use of antibiotic prophylaxis at the time of replacement $(n=70)$; and Cheung and colleagues compared two different types of cleaning solutions $(n=20)$.

All the included trials were small and under-powered. The reporting of the trials was inadequate and as a result, risk of bias assessment was judged to be unclear for the majority of the domains in two out of the three trials. There was insufficient evidence to indicate that (i) there was a lower incidence of symptomatic UTI in people whose catheter was changed both monthly and when clinically indicated (risk ratio (RR) 0.35 , $95 \%$ confidence interval ( $\mathrm{Cl}) 0.13$ to 0.95 ; very low quality evidence) compared to only when clinically indicated, (ii) there was not enough evidence to assess the effect of antibiotic prophylaxis on reducing: positive urine cultures at 7 days ( $\mathrm{RR} 0.91,95 \% \mathrm{Cl} 0.79$ to 1.04 ); 
infection (RR $1.41,95 \% \mathrm{Cl} 0.55$ to 3.65); or death (RR 2.12, 95\% Cl 0.20 to 22.30 ; very low quality evidence), (iii) there was no statistically significant difference in the incidence of asymptomatic bacteruria at 7 days (RR $0.80,95 \% \mathrm{Cl} 0.42$ to 1.52 ) between people receiving water or chlorhexidine solution for periurethral cleansing at the time of catheter replacement. However, none of the 16 participants developed a symptomatic catheter-associated urinary tract infection (CAUTI) at day 14.

The following outcomes were considered critical for decision-making and were also selected for the 'Summary of findings' table: (i) participant satisfaction, (ii) condition-specific quality of life, (iii) urinary tract trauma, and (iv) formal economic analysis. However, none of the trials reported these outcomes.

None of the trials compared the following comparisons: (i) replacing catheter versus other policy e.g. washouts, (ii) replacing in the home environment versus clinical environment, (iii) clean versus aseptic technique for replacing catheter, (iv) lubricant A versus lubricant B or no lubricant, and $(v)$ catheter user versus carer versus health professional performing the catheter replacement procedure.

\section{Authors' conclusions}

There is currently insufficient evidence to assess the value of different policies for replacing long-term urinary catheters on patient outcomes. In particular, there are a number of policies for which there are currently no trial data; and a number of important outcomes which have not been assessed, including patient satisfaction, quality of life, urinary tract trauma, and economic outcomes. There is an immediate need for rigorous, adequately powered randomised controlled trials which assess important clinical outcomes and abide by the principles and recommendations of the CONSORT statement.

\section{PLAIN LANGUAGE SUMMARY}

\section{Policies for replacing long-term indwelling urinary catheters in adults}

\section{Background information}

A urinary catheter is a tube that is inserted into the bladder from the end of the urethra to drain urine from the bladder. Usually, urinary catheters are only required for a few days, such as after an operation. However, there are some medical conditions that may require bladder drainage on a long-term basis. There are many different ways to care for and maintain a long-term urinary catheter. In this review we refer to these different care methods as health-care 'policies'. Examples of policies that relate to the replacement of a long-term catheter include: time between catheter replacements; use of antibiotics during replacement; use of cleaning solutions or lubricants during replacement; and personnel, environment and techniques used at replacement. This review aimed to identify which policies at the time of long-term catheter replacement were most effective in improving patient care.

\section{The main findings of the review}

This review identified that there is currently insufficient high-quality evidence which evaluates the effectiveness of different policies for replacing long-term urinary catheters. Only three randomised clinical trials, which included a total of 107 participants, were eligible and included in this review.

These trials evaluated: (i) different time intervals for catheter replacement, (ii) the use of antibiotics to prevent infection and (iii) the use of different cleaning solutions. There was insufficient evidence to suggest that replacing the catheter monthly and when there was a clinical reason to do so reduced bacteria in the urine compared to replacing the catheter only when there was a clinical reason to do so. However, there was not enough evidence to say whether using antibiotics at the time of replacing the catheter for prevention of infection was effective or whether using water to cleanse during catheter replacement was as effective as an anti-bacterial washing solution.

\section{Adverse effects}

None of the trials reported any adverse effects relating to the policies investigated.

\section{Any limitations of the review}

All three trials which were included in this review were very small with methodological flaws. Therefore new trials are needed in order to definitely answer this research question. The evidence in this review is current up to 19 May 2016. 


\begin{tabular}{|c|c|c|c|c|c|c|}
\hline \multicolumn{7}{|c|}{$\begin{array}{l}\text { S U M M A R Y O F F I N D I N G S } \\
\text { Summary of findings for the main comparison. } \\
\text { indwelling urinary catheters in adults }\end{array}$} \\
\hline \multicolumn{7}{|c|}{ Monthly \& PRN catheter replacement versus PRN catheter replacement for replacing long-term indwelling urinary catheters in adults } \\
\hline \multicolumn{7}{|c|}{$\begin{array}{l}\text { Patient or population: adults with replacing long-term indwelling urinary catheters } \\
\text { Settings: USA veterans administration nursing home } \\
\text { Intervention: Monthly \& PRN catheter replacement versus PRN catheter replacement }\end{array}$} \\
\hline \multirow[t]{3}{*}{ Outcomes } & \multicolumn{2}{|c|}{ Illustrative comparative risks ${ }^{\star}(95 \% \mathrm{Cl})$} & \multirow{3}{*}{$\begin{array}{l}\text { Relative effect } \\
(95 \% \mathrm{Cl})\end{array}$} & \multirow{3}{*}{$\begin{array}{l}\text { No of Partici- } \\
\text { pants } \\
\text { (studies) }\end{array}$} & \multirow{3}{*}{$\begin{array}{l}\text { Quality of the } \\
\text { evidence } \\
\text { (GRADE) }\end{array}$} & \multirow[t]{3}{*}{ Comments } \\
\hline & Assumed risk & Corresponding risk & & & & \\
\hline & Control & $\begin{array}{l}\text { Monthly \& PRN catheter } \\
\text { replacement versus PRN } \\
\text { catheter replacement }\end{array}$ & & & & \\
\hline $\begin{array}{l}\text { Symptomatic CAUTI as defined by trial- } \\
\text { ists }\end{array}$ & 857 per 1000 & $\begin{array}{l}300 \text { per } 1000 \\
(111 \text { to } 814)\end{array}$ & $\begin{array}{l}\text { RR } 0.35 \\
(0.13 \text { to } 0.95)\end{array}$ & $\begin{array}{l}17 \\
\text { (1 study) }\end{array}$ & $\begin{array}{l}\oplus \ominus \odot \odot \\
\text { very low } 1,2\end{array}$ & \\
\hline Participant satisfaction - not reported & See comment & See comment & Not estimable & - & See comment & \\
\hline $\begin{array}{l}\text { Condition-specific quality-of-life mea- } \\
\text { sures - not reported }\end{array}$ & See comment & See comment & Not estimable & - & See comment & \\
\hline $\begin{array}{l}\text { Adverse effects (Urinary tract trauma) - } \\
\text { not reported }\end{array}$ & See comment & See comment & Not estimable & - & See comment & \\
\hline Adverse effects (Death) - not reported & See comment & See comment & Not estimable & - & See comment & \\
\hline $\begin{array}{l}\text { Formal economic analysis - not report- } \\
\text { ed }\end{array}$ & See comment & See comment & Not estimable & - & See comment & \\
\hline \multicolumn{7}{|c|}{$\begin{array}{l}\text { *The basis for the assumed risk (e.g. the median control group risk across studies) is provided in footnotes. The corresponding risk (and its } 95 \% \mathrm{Cl} \text { ) is based on the as- } \\
\text { sumed risk in the comparison group and the relative effect of the intervention (and its } 95 \% \mathrm{Cl} \text { ). } \\
\text { Cl: Confidence interval; RR: Risk ratio; }\end{array}$} \\
\hline
\end{tabular}

GRADE Working Group grades of evidence

High quality: Further research is very unlikely to change our confidence in the estimate of effect.

Moderate quality: Further research is likely to have an important impact on our confidence in the estimate of effect and may change the estimate.

Low quality: Further research is very likely to have an important impact on our confidence in the estimate of effect and is likely to change the estimate. 


\begin{tabular}{|c|c|c|c|c|c|c|}
\hline \multicolumn{7}{|c|}{ Very low quality: We are very uncertain about the estimate } \\
\hline \multirow{2}{*}{\multicolumn{7}{|c|}{$\begin{array}{l}1 \text { Downgraded two levels: Sequence generation, allocation concealment and blinding of outcome assessment was judged to be unclear. Blinding of participants and personnel } \\
\text { was judged to be at high risk of bias.The outcome was reported by one under-power study. } \\
2 \text { Downgraded one level: As the sample size and the event rate is small. } \\
\text { PRN: from the Latin "pro re nata", meaning "as needed". } \\
\text { Summary of findings 2. Antibiotics at time of replacement versus no antibiotics at time of replacement for replacing long-term indwelling urinary } \\
\text { catheters in adults }\end{array}$}} \\
\hline & & & & & & \\
\hline \multicolumn{7}{|c|}{ Antibiotics at time of replacement versus no antibiotics at time of replacement for replacing long-term indwelling urinary catheters in adults } \\
\hline \multicolumn{7}{|c|}{$\begin{array}{l}\text { Patient or population: adults with replacing long-term indwelling urinary catheters } \\
\text { Settings: Geriatric Centre in Israel } \\
\text { Intervention: Antibiotics at time of replacement versus no antibiotics at time of replacement }\end{array}$} \\
\hline \multirow[t]{3}{*}{ Outcomes } & \multicolumn{2}{|c|}{ Illustrative comparative risks* $(95 \% \mathrm{CI})$} & \multirow{3}{*}{$\begin{array}{l}\text { Relative effect } \\
(95 \% \mathrm{CI})\end{array}$} & \multirow{3}{*}{$\begin{array}{l}\text { No of Partici- } \\
\text { pants } \\
\text { (studies) }\end{array}$} & \multirow{3}{*}{$\begin{array}{l}\text { Quality of the } \\
\text { evidence } \\
\text { (GRADE) }\end{array}$} & \multirow[t]{3}{*}{ Comments } \\
\hline & Assumed risk & Corresponding risk & & & & \\
\hline & Control & $\begin{array}{l}\text { Antibiotics at time of re- } \\
\text { placement versus no antibi- } \\
\text { otics at time of replacement }\end{array}$ & & & & \\
\hline Symptomatic CAUTI - not reported & See comment & See comment & Not estimable & - & See comment & \\
\hline $\begin{array}{l}\text { Participant satisfaction - not report- } \\
\text { ed }\end{array}$ & See comment & See comment & Not estimable & - & See comment & \\
\hline $\begin{array}{l}\text { Condition-specific quality of life } \\
\text { measures - not reported }\end{array}$ & See comment & See comment & Not estimable & - & See comment & \\
\hline $\begin{array}{l}\text { Adverse effects (Urinary tract trauma) } \\
\text { - not reported }\end{array}$ & See comment & See comment & Not estimable & - & See comment & \\
\hline Adverse effects (Death) & 28 per 1000 & $\begin{array}{l}59 \text { per } 1000 \\
\text { (6 to } 619)\end{array}$ & $\begin{array}{l}\text { RR } 2.12 \\
(0.20 \text { to } 22.20)\end{array}$ & $\begin{array}{l}70 \\
\text { (1 study) }\end{array}$ & $\begin{array}{l}\oplus \odot \odot \odot \\
\text { very low 1,3 }\end{array}$ & \\
\hline $\begin{array}{l}\text { Formal economic analysis - not re- } \\
\text { ported }\end{array}$ & See comment & See comment & Not estimable & & & \\
\hline
\end{tabular}

\section{Summary of findings 2. Antibiotics at time of replacement versus no antibiotics at time of replacement for replacing long-term indwelling urinary}

Patient or population: adults with replacing long-term indwelling urinary catheters

Settings: Geriatric Centre in Israel

Intervention: Antibiotics at time of replacement versus no antibiotics at time of replacement 


\begin{tabular}{|c|c|c|c|c|c|c|}
\hline \multicolumn{7}{|c|}{$\begin{array}{l}\text { *The basis for the assumed risk (e.g. the median control group risk across studies) is provided in footnotes. The corresponding risk (and its } 95 \% \mathrm{Cl} \text { ) is based on the as- } \\
\text { sumed risk in the comparison group and the relative effect of the intervention (and its } 95 \% \mathrm{Cl} \text { ). } \\
\text { Cl: Confidence interval; RR: Risk ratio; }\end{array}$} \\
\hline \multicolumn{7}{|c|}{$\begin{array}{l}\text { GRADE Working Group grades of evidence } \\
\text { High quality: Further research is very unlikely to change our confidence in the estimate of effect. } \\
\text { Moderate quality: Further research is likely to have an important impact on our confidence in the estimate of effect and may change the estimate. } \\
\text { Low quality: Further research is very likely to have an important impact on our confidence in the estimate of effect and is likely to change the estimate. } \\
\text { Very low quality: We are very uncertain about the estimate. }\end{array}$} \\
\hline \multicolumn{7}{|c|}{ 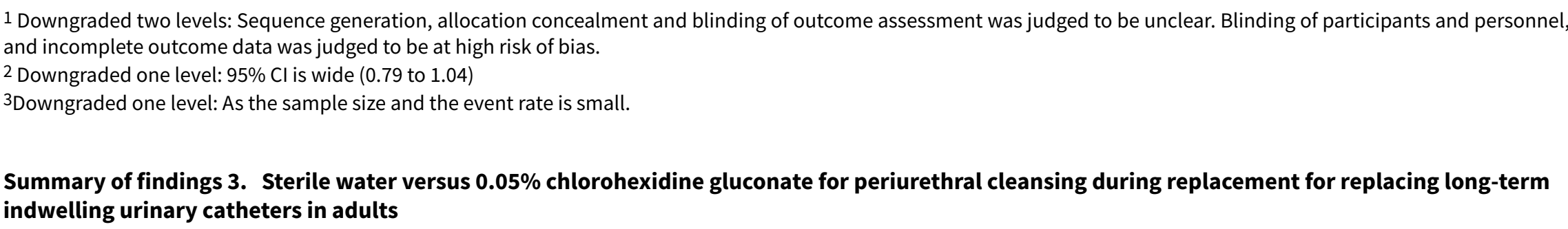 } \\
\hline \multicolumn{7}{|c|}{ Sterile water versus $0.05 \%$ chlorohexidine gluconate for periurethral cleansing during replacement for replacing long-term indwelling urinary catheters in adults } \\
\hline \multicolumn{7}{|c|}{$\begin{array}{l}\text { Patient or population: adults with replacing long-term indwelling urinary catheters } \\
\text { Settings: Hong Kong Community Nursing Service } \\
\text { Intervention: Sterile water versus } 0.05 \% \text { chlorohexidine gluconate for periurethral cleansing during replacement }\end{array}$} \\
\hline \multirow[t]{3}{*}{ Outcomes } & Illustrative co & rative risks* $(95 \% \mathrm{Cl})$ & \multirow{3}{*}{$\begin{array}{l}\text { Relative effect } \\
(95 \% \mathrm{Cl})\end{array}$} & \multirow{3}{*}{$\begin{array}{l}\text { No of Partici- } \\
\text { pants } \\
\text { (studies) }\end{array}$} & \multirow{3}{*}{\multicolumn{2}{|c|}{$\begin{array}{l}\text { Quality of the } \\
\text { evidence } \\
\text { (GRADE) }\end{array}$}} \\
\hline & Assumed risk & Corresponding risk & & & & \\
\hline & Control & $\begin{array}{l}\text { Sterile water versus } 0.05 \% \\
\text { chlorohexidine gluconate } \\
\text { for periurethral cleansing } \\
\text { during replacement }\end{array}$ & & & & \\
\hline \multirow{2}{*}{$\begin{array}{l}\text { Symptomatic CAUTI at } 14 \text { days after } \\
\text { replacement }\end{array}$} & \multicolumn{2}{|c|}{ Study population } & \multirow[t]{2}{*}{ Not estimable } & \multirow{2}{*}{$\begin{array}{l}16 \\
\text { (1 study) }\end{array}$} & \multirow{2}{*}{\multicolumn{2}{|c|}{$\begin{array}{l}\oplus \Theta \Theta \Theta \\
\text { very low } 1,2\end{array}$}} \\
\hline & 0 per 1000 & $\begin{array}{l}\text { O per } 1000 \\
(0 \text { to } 0)\end{array}$ & & & & \\
\hline Participant satisfaction - not reported & See comment & See comment & Not estimable & - & See comment & \\
\hline $\begin{array}{l}\text { Condition-specific quality of life mea- } \\
\text { sures - not reported }\end{array}$ & See comment & See comment & Not estimable & - & See comment & \\
\hline
\end{tabular}




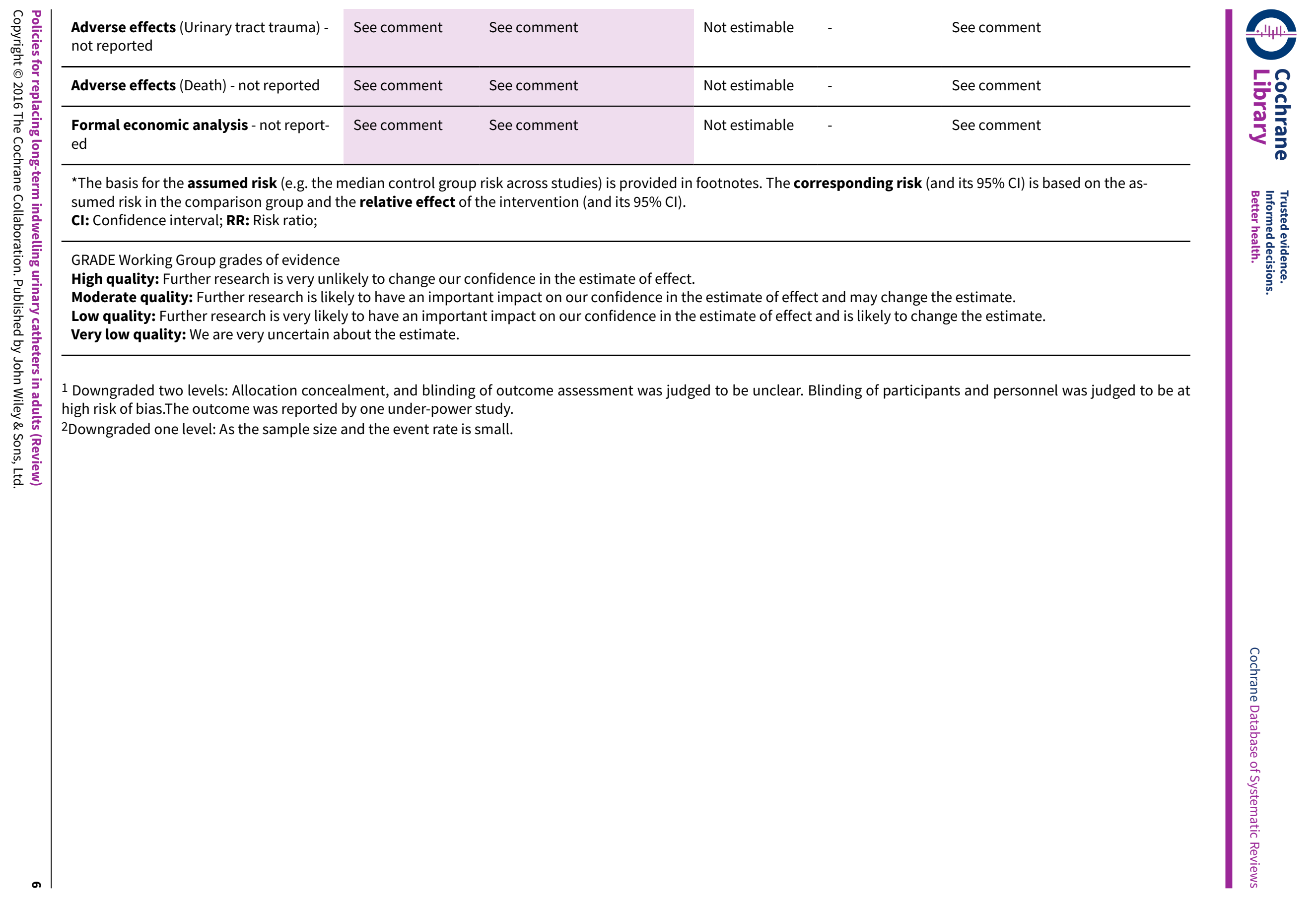




\section{B A C K G R O U N D}

\section{Description of the condition}

Long-term indwelling urinary catheters can be used in the care of people with urinary incontinence or urinary retention. These conditions can arise from a variety of underlying pathologies that cause dysfunction of bladder storage or emptying, such as multiple sclerosis and benign prostatic hyperplasia. The prevalence of long-term catheter use varies between countries and health-care settings (Stensballe 2005). A study by Sørbye and colleagues found that, in Italy, $35.9 \%$ of male and $27.4 \%$ of female elderly home care clients used either an indwelling, intermittent or condom catheter. However, rates of use of these catheters were lower in men in Finland (2.9\%) and in women in the Czech Republic (0.6\%) (Sørbye 2009). There are many well recognised and common complications associated with the use of long-term urinary catheters, including urinary tract infections, encrustation due to mineral deposits, and peri-catheter leakage. The majority of micro-organisms that cause catheter-associated urinary tract infections (CAUTIS) are derived from the patient's own colonic and perineal flora and the hands of health-care professionals involved in catheter insertion or management (Maki 2001). Studies have shown a 5\% to $8 \%$ increase in the risk of developing bacteruria for each day following catheterisation, and that almost all users will have bacteruria four weeks after long-term catheter insertion (Gould 2010; Nicolle 2001; Stamm 1991). Leakage, blockage, pain and dislodgement of long-term catheters are also recognised as commonly occurring problems that often require additional use of health-care resources and services (Wilde 2013). These complications will undoubtedly have an impact on patient quality of life and satisfaction.

\section{Description of the intervention}

A number of different policies can be employed during the time of catheter replacement. These policies are described below.

\section{Time between replacements}

The recommended time between catheter replacement depends on local policies and varies significantly between centres (Palka 2014; Willson 2009). This discrepancy in clinical practice reflects a lack of evidence to support the early or late replacement of long-term urinary catheters in the reduction of adverse outcomes. The Infectious Diseases Society of America (IDSA) states there is currently insufficient data to recommend a specific time interval between long-term catheter or suprapubic catheter replacement (Hooton 2010). A shorter time interval between catheter replacements may reduce the development of a biofilm that can act to harbour bacteria, and may also reduce the likelihood of mechanical blockage. However, the tissue disruption caused by more frequent catheter replacement could contribute to the development of CAUTI and other adverse outcomes.

\section{Antibiotics as prophylaxis}

For people requiring a long-term indwelling catheter, antibiotics may be given prophylactically in an attempt to prevent CAUTI development or at the time of developing the symptoms associated with CAUTI. However, prophylactic antibiotics have been shown to permit the development of resistant organisms (Hooton 2010). A comparison of prophylactic, clinically indicated and microbiologically indicated antibiotics has been previously explored in another Cochrane Review (Lusardi 2013). This concluded that data was limited and that there was insufficient evidence to determine best practice.

\section{Catheter replacement environments, personnel and techniques}

Long-term indwelling urinary catheters can be replaced by personal carers, health-care professionals or by the catheter users themselves. Furthermore, the procedure may be carried out by the catheter user in their own home, by a health-care professional visiting the user at home, or by a health-care professional in a clinical environment or nursing home. Catheter replacement can be performed using either a clean or an aseptic approach. A clean approach involves the use of non-sterile gloves and the cleansing of the external urethral meatus and surrounding area with a nonantiseptic solution. An aseptic approach involves the use of sterile gloves, sterile barriers, antiseptic cleaning solutions and a nontouch technique. Clinical practice worldwide varies according to local policies, individual preferences and the specific clinical setting (Willson 2009). A previous Cochrane Reviewconcluded that existing data does not provide convincing evidence that any specific technique (aseptic or clean), catheter type (coated or uncoated), method (single use or multiple use), or person (self or other) can be considered as the gold standard in the use of intermittent catheters (Moore 2007).

\section{Cleaning solutions}

There are various cleaning solutions which can be used when replacing catheters, including sterile water, chlorhexidine gluconate and povidone-iodine. The cleaning procedure may include cleaning the perineal area as well as the periurethral area. Catheters may also be cleaned instead of replaced. Washout policies for catheters have been evaluated by a previous Cochrane review (Hagen 2010). The review indicated that "the evidence was too scanty to conclude whether or not washouts were beneficial".

\section{Lubricants}

Lubricants are commonly used in most types of urethral catheterisation to allow for easier insertion and patient comfort and typically contain local anaesthetic and antiseptic. The administration of lubricants can be incorporated into either a clean or an aseptic catheterisation technique.

\section{Other catheter reviews}

This review is one of a series of Cochrane Reviews addressing different issues in the use of catheters for long-term management of catheter users for a variety of conditions. These include:

- Washout policies in long-term indwelling urinary catheterisation in adults (Hagen 2010)

- Types of indwelling urinary catheters for long-term bladder drainage in adults (Jahn 2007)

- Long-term bladder management by intermittent catheterisation in adults and children (Moore 2007)

- Urinary catheter policies for long-term bladder drainage (NiëlWeise 2005).

\section{Why it is important to do this review}

Long-term indwelling urinary catheters are used commonly in health care. Guidelines and protocols exist worldwide but are not supported by extensive or high-quality evidence. It is important 
that policies for replacing long-term indwelling urinary catheters are updated based on all of the existing high-quality evidence. There is an immediate need to improve the rates of adverse effects and optimise patient quality of life, patient and carer satisfaction and resource management associated with long-term catheter use. The review will also identify the specific needs for future research in this area.

\section{OB JECTIVES}

To determine the effectiveness of different policies for replacing long-term indwelling urinary catheters in adults.

\section{METHODS}

\section{Criteria for considering studies for this review}

\section{Types of studies}

Randomised controlled trials (RCTs) or quasi-RCTs.

\section{Types of participants}

Adults (over the age of 18 years) with long-term ( $>14$ days) indwelling urinary or suprapubic catheters that are anticipated to require replacement.

\section{Types of interventions}

The following types of interventions were compared with each other:

1. One interval versus another interval between catheter replacement

2. Antibiotic prophylaxis versus no prophylaxis at the time of catheter replacement

3. Replacing catheter versus other policy e.g. washouts

4. Replacing in home environment versus clinical environment

5. Clean versus aseptic technique for replacing catheter

6. Cleaning solution $A$ versus cleaning solution $B$

7. Lubricant $A$ versus lubricant $B$ or no lubricant

8. Catheter users versus carer versus health professional performing the catheter replacement procedure

This review did not include: type/material of catheter (Jahn 2007), washout versus no washout in long-term indwelling urinary catheters (Hagen 2010), long-term antibiotics (Niël-Weise 2005), and the use of intermittent catheters (Moore 2004), as these areas have been addressed in other Cochrane Reviews.

\section{Types of outcome measures}

\section{Primary outcomes}

- Participant satisfaction

- Symptomatic catheter-associated urinary tract infection (CAUTI) as defined by trialists

\section{Secondary outcomes}

\section{Participant-reported quality of life}

- Generic quality-of-life measures

- Condition-specific quality-of-life measures

- Psychological outcome measures

\section{Clinician-reported outcomes}

- Clinician satisfaction

- Number of participants requiring more frequent replacements (than per protocol)

- Duration of use of single catheter

\section{Carer-reported outcomes}

- Carer satisfaction

\section{Adverse effects}

- Urinary tract trauma

- Pain/discomfort

- Haematuria

- Asymptomatic bacteruria

- Systemic infection (septicaemia)

- Encrustation/breakdown of catheter

- Pericatheter leakage

- Stricture formation

- Failure to achieve catheter replacement

- Hospitalisation

- Bladder calculi

- Bladder cancer

\section{Economic outcomes}

- Cost of intervention

- Resource implications

- Formal economic analysis (cost effectiveness)

\section{Other outcomes}

Any other outcomes considered to be important if reported in trials.

\section{Search methods for identification of studies}

We did not impose any restrictions, for example language or publication status, on the searches described below.

\section{Electronic searches}

This review drew on the search strategy developed for Cochrane Incontinence. We identified relevant trials from the Cochrane Incontinence Specialised Trials Register. For more details of the search methods used to build the Specialised Register please see the Group's module in The Cochrane Library. The Register contains trials identified from the Cochrane Central Register of Controlled Trials (CENTRAL), MEDLINE, MEDLINE In-Process, MEDLINE Epub Ahead of Print, CINAHL, ClinicalTrials.gov, WHO ICTRP , UK Clinical Research Network Portfolio and handsearching of journals and conference proceedings. Many of the trials in the Cochrane Incontinence Specialised Register are also contained in CENTRAL. The date of the last search was 19 May 2016.

The terms used to search the Cochrane Incontinence Specialised Register are given in Appendix 1.

\section{Searching other resources}

We searched the reference lists of relevant articles. 


\section{Data collection and analysis}

\section{Selection of studies}

We included only randomised and quasi-randomised controlled trials. At least two review authors independently screened the list of titles and abstracts generated by our search. We retrieved fulltext articles of potentially relevant studies. At least two review authors independently assessed the full-text articles for eligibility. We contacted study investigators for additional information when required. We resolved any differences of opinion by discussion or involvement of a third party. We listed studies formally considered for the review that were subsequently excluded along with the reasons for their exclusion.

\section{Data extraction and management}

Two of the review authors independently extracted data of the included studies by using a standardised form. Any disagreement was resolved by discussion or by consulting a third party. We contacted study authors when there was insufficient information regarding the primary outcome in the published reports or when additional information was required. We used Review Manager software (RevMan 5.3) for data entry. We processed the included trial data according to the Cochrane Handbook for Systematic Reviews of Interventions (Higgins 2011).

\section{Assessment of risk of bias in included studies}

We assessed the risk of bias in the included studies using the Cochrane 'Risk of bias' assessment tool (Higgins 2011). This included assessment of:

- sequence generation

- allocation concealment

- blinding of participants or therapists

- blinding of outcome assessors

- completeness of outcome data

- selective outcome reporting

- other potential sources of bias

Two of the review authors independently assessed these domains and rated each as 'high risk', 'low risk' or 'unclear risk'. We resolved any differences of opinion by consensus or by consulting a third party.

\section{Measures of treatment effect}

We based analysis on available data from all included trials relevant to the comparisons and outcomes of interest. For trials with multiple publications, only the most up-to-date or complete data for each outcome were included.

For categorical outcomes we related the numbers reporting an outcome to the numbers at risk in each group to calculate a risk ratio (RR) with 95\% confidence interval (Cl). For continuous variables we planned to use means and standard deviations to calculate a mean difference (MD) with $95 \% \mathrm{Cl}$; however no continuous variables were encountered.

If we had found similar outcomes reported on different scales, we would have calculated the standardised mean difference (SMD). We would have reversed the direction of effect, when necessary, to ensure consistency across trials. If data to calculate RRs or
MDs were not given, we would have utilised the most detailed numerical data available to calculate the actual numbers or means and standard deviations (for example test statistics, $P$ values).

\section{Unit of analysis issues}

In simple parallel group designs, when participants are individually randomised, the primary analysis was per participant randomised. We analysed studies with multiple treatment groups by treating each pair of arms as a separate comparison, as appropriate. We planned to undertake analysis of studies with non-standard designs, such as cross-over trials and cluster-randomised trials, as described in the Cochrane Handbook for Systematic Reviews of Interventions (Higgins 2011); however no such trials were included.

\section{Dealing with missing data}

We analysed data on an intention-to-treat basis, as far as possible, meaning that all participants were analysed in the groups to which they are randomised. We made attempts to obtain missing data from the original trialists. Where this was not possible, we reported the data as given in the studies.

If trials had reported sufficient detail to calculate MDs but gave no information on associated standard deviations (SD), we would have assumed the outcome had an SD equal to the highest SD from other trials within the same analysis. We did not need to do this as metaanalysis was not performed.

\section{Assessment of heterogeneity}

We did not perform any assessment of heterogeneity as none of the pre-specified comparisons were addressed by more than one trial. We had intended to combine trials only if they were thought to be clinically similar. We would have assessed heterogeneity between studies by visual inspection of the plots of data, the $\mathrm{Chi}^{2}$ test for heterogeneity and the $I^{2}$ statistic (Higgins 2011). We would have defined the thresholds for interpretation of the $I^{2}$ statistic according to the Cochrane Handbook for Systematic Reviews of Interventions (Higgins 2011).

\section{Assessment of reporting biases}

In view of the difficulty of detecting and correcting for publication bias and other reporting biases, we aimed to minimise their potential impact by ensuring a comprehensive search for eligible studies and by being alert to duplication of data. We encountered no duplication of data as no comparison was investigated by more than one trial.

\section{Data synthesis}

We intended to combine trials if interventions were similar, based on clinical criteria; however we did not find more than one study addressing any pre-specified comparison. We would have conducted a meta-analysis with a fixed-effect model to combine trial data unless there had been evidence of heterogeneity across studies.

\section{Subgroup analysis and investigation of heterogeneity}

We intended to perform sub-group analysis in order to explore the impact of these sub-groups on the interventions. We selected the following sub-groups: 


\section{Different catheter materials}

Catheter material is a key determinant of encrustation (and presumably blockage) and this is directly linked to the interval between replacements. Antimicrobial impregnation of the catheter or use of special low-friction catheters could impact the need for antibiotic prophylaxis or a lubricant.

\section{Participants over $\mathbf{7 5}$ versus participants under $\mathbf{7 5}$}

Elderly people have unique anatomical and functional changes, both local and systemic. Elderly individuals are more likely to have voiding dysfunction, altered lower urinary tract anatomy, comorbidities, impaired immune function and poor local hygiene. These could have an impact on antimicrobial policy, health-care setting for catheter change or use of an aseptic technique. The authors have chosen 75 years as a marker for the age at which these issues would likely be most relevant.

\section{Sex: male versus female}

Sex of the individual can influence the interventions under study. The unique anatomy of the female perineum makes women more prone to urinary infections but also renders catheter change technically easy. Men with gross prostatic enlargement could pose technical problems in catheter change demanding greater skill and a hospital setting.

\section{Level of care: community/self-care versus residential/assisted living}

The level of care such as community care, self care or an assisted facility could potentially have an impact on the policies chosen with regard to catheter change in people requiring long-term urinary catheters.

\section{Condition requiring catheterisation}

\section{Non-neurological versus neurological reason for indwelling catheter}

The underlying condition could have an impact on the chosen policy. For example catheter change in people with neurogenic lower urinary tract dysfunction could be associated with distinct challenges. People with neurogenic bladder on longterm indwelling catheters are usually clinically advised to receive intermittent catheterisation. Many of these people have poor hand function, quadriplegia or impaired cognition and these factors are more likely to be associated with poor local hygiene, impaired nutrition and immunity. Some people with neurogenic dysfunction might have elevated bladder pressures in the form of severe neurogenic detrusor overactivity or poor compliance with consequent risk to the upper urinary tracts. This could conceivably make them more prone to sepsis during urethral manipulations.

\section{People with retention versus those with incontinence}

People with incontinence requiring an indwelling catheter are more likely to have cognitive impairment, limited ambulation or neurological disease such as Parkinsonism or stroke; while those with intractable retention are more likely to be suffering from severe cardiovascular or pulmonary disease. All these can influence the interventions under study in unique ways.

However, subgroup analysis could not be performed due to the lack of included trials.

\section{Sensitivity analysis}

We intended to conduct sensitivity analyses by including or excluding trials we judged as high risk of bias. We did not conduct sensitivity analyses because meta-analysis was not performed.

\section{Quality of evidence}

Primary and secondary outcomes, as defined above, were classified by the review authors as 'critical', 'important' or 'not important' for decision making from the patients' perspective (Gould 2010; Guyatt 2011a; Guyatt 2011b; Guyatt 2013a; Guyatt 2013b). The GRADE Working Group recommend including up to seven outcomes in a systematic review. In this systematic review, GRADE methodology was adopted for assessing the quality of the evidence for the following outcomes classified as critical:

- Symptomatic CAUTI as defined by trialists

- Participant satisfaction

- Condition-specific quality-of-life measures

- Adverse effects (urinary tract trauma)

- Adverse effects (death)

- Formal economic analysis

\section{RES U L T S}

\section{Description of studies}

\section{Results of the search}

We screened a total of 1125 records, identified by the literature search, for this review. From these records, we considered 61 for full text screening, of which we deemed three were suitable for inclusion in this review (Cheung 2008; Firestein 2001; Priefer 1982). The flow of literature through the assessment process is shown in the PRISMA flowchart (Figure 1). 
Figure 1. PRISMA study flow diagram

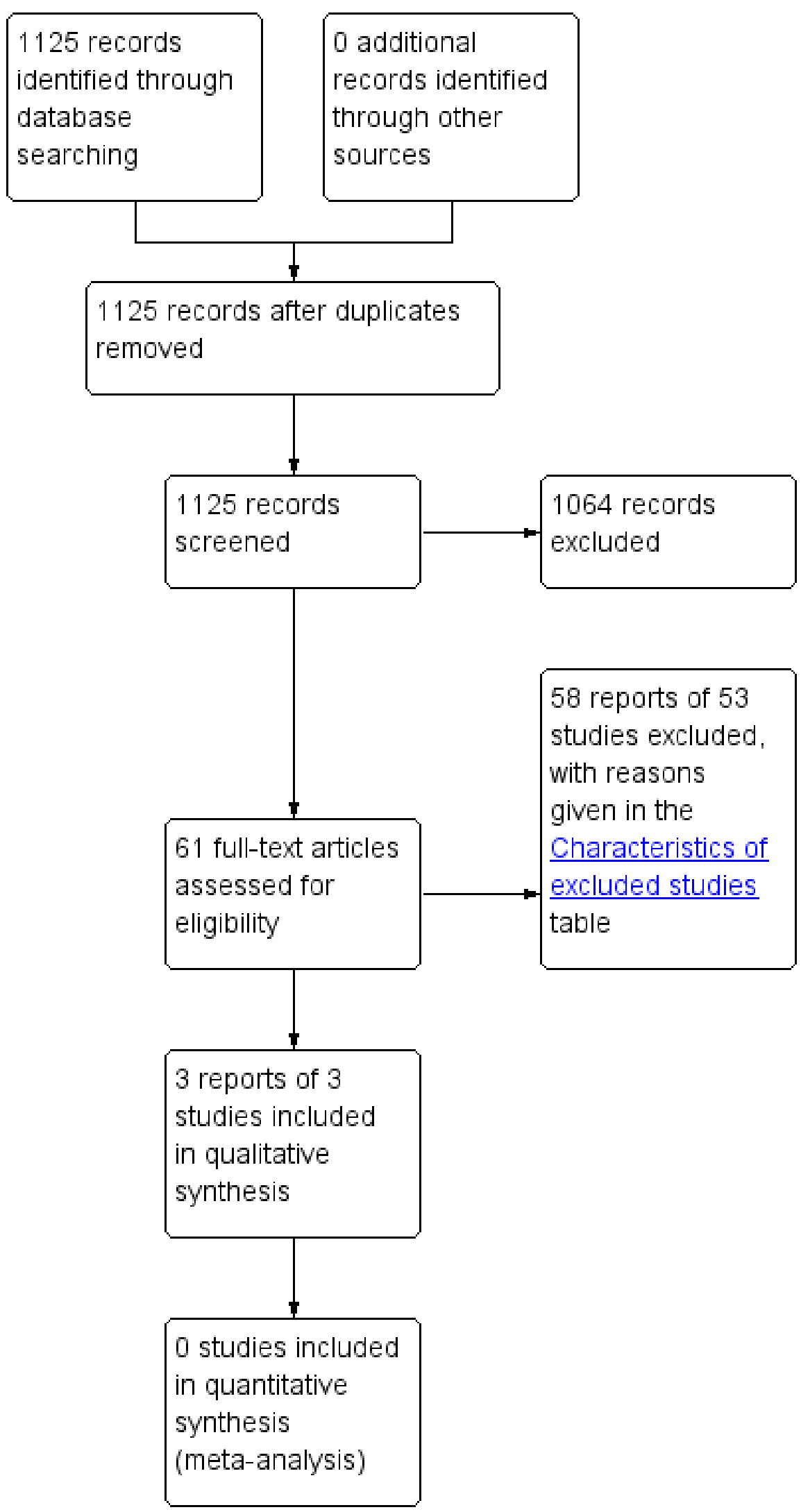




\section{Included studies}

Cheung 2008 randomised 20 subjects (6 males, 14 females) in a Hong Kong community nursing service to either sterile water or conventional $0.05 \%$ chlorhexidine gluconate for periurethral cleansing prior to insertion of a replacement of long-term urinary catheter. Subjects were excluded if they had a symptomatic UTI at the time of the replacement, were on antibiotic treatment or if they had only been using a long-term catheter for less than one month. The mean age of the subjects was $78.4(\mathrm{SD}=11.8$ ) years, and $55 \%$ lived in a nursing home. Urine cultures were taken from participants at baseline and then 1, 7 and 14 days after catheter replacement. Reported outcomes were colonisation counts greater than $10^{5} \mathrm{cfu} /$ $\mathrm{mL}$ and incidence of symptomatic CAUTIs.

Firestein 2001 randomised 70 subjects ( 21 males, 49 females) in a geriatric centre in Israel to receive either $1 \mathrm{~g}$ of intravenous meropenem 30 minutes before long-term catheter replacement or no antibiotic before replacement. Subjects were excluded if their urinary catheter had been in place for less than 4 weeks or if there had been antibiotic use within the 2-week period before enrolment. The mean age of the subjects was 79.3 (SD = 9.6) years. Urine cultures were taken from participants at baseline and then 3, 7, 14 and 28 days after catheter replacement. Reported outcomes were positive urine cultures, incidence of infection, incidence of bacteraemia and death.
Priefer 1982 randomised 17 men in a USA veterans administration nursing home to catheter replacements either: only for obstruction and/or infection or monthly as well as when indicated by obstruction and/or infection. Subjects who required transfer to a hospital for acute problems unrelated to the urinary tract were excluded. The mean age of subjects was 77.1 (SD = 16.3) years in the control group and $83.4(S D=7.9)$ years in the intervention group. Participants were observed over a six-month period and the following outcomes were reported: total number of irrigations required; number of catheter changes per month required; incidence of symptomatic CAUTI over the six months.

\section{Excluded studies}

We have listed the excluded studies along with reasons for exclusion in the Characteristics of excluded studies table. The most common reason for excluding studies was that the intervention did not relate to replacing long-term catheters.

\section{Risk of bias in included studies}

Detailed results of the 'Risk of bias' assessment are provided in Figure 2; Figure 3 and judgement of individual domains are summarised below.

Figure 2. Risk of bias graph: review authors' judgements about each risk of bias item presented as percentages across all included studies.

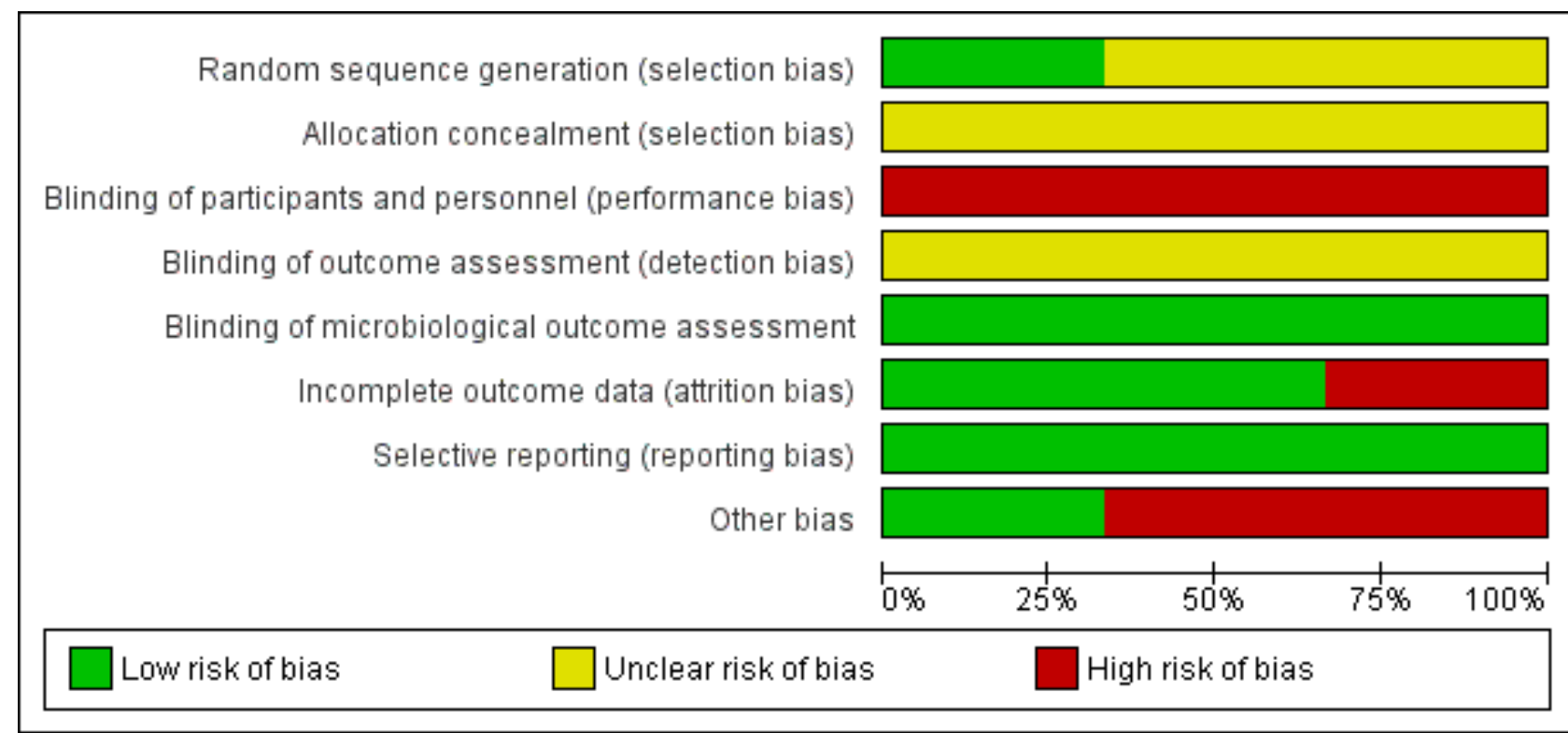


Figure 3. Risk of bias summary: review authors' judgements about each risk of bias item for each included study.

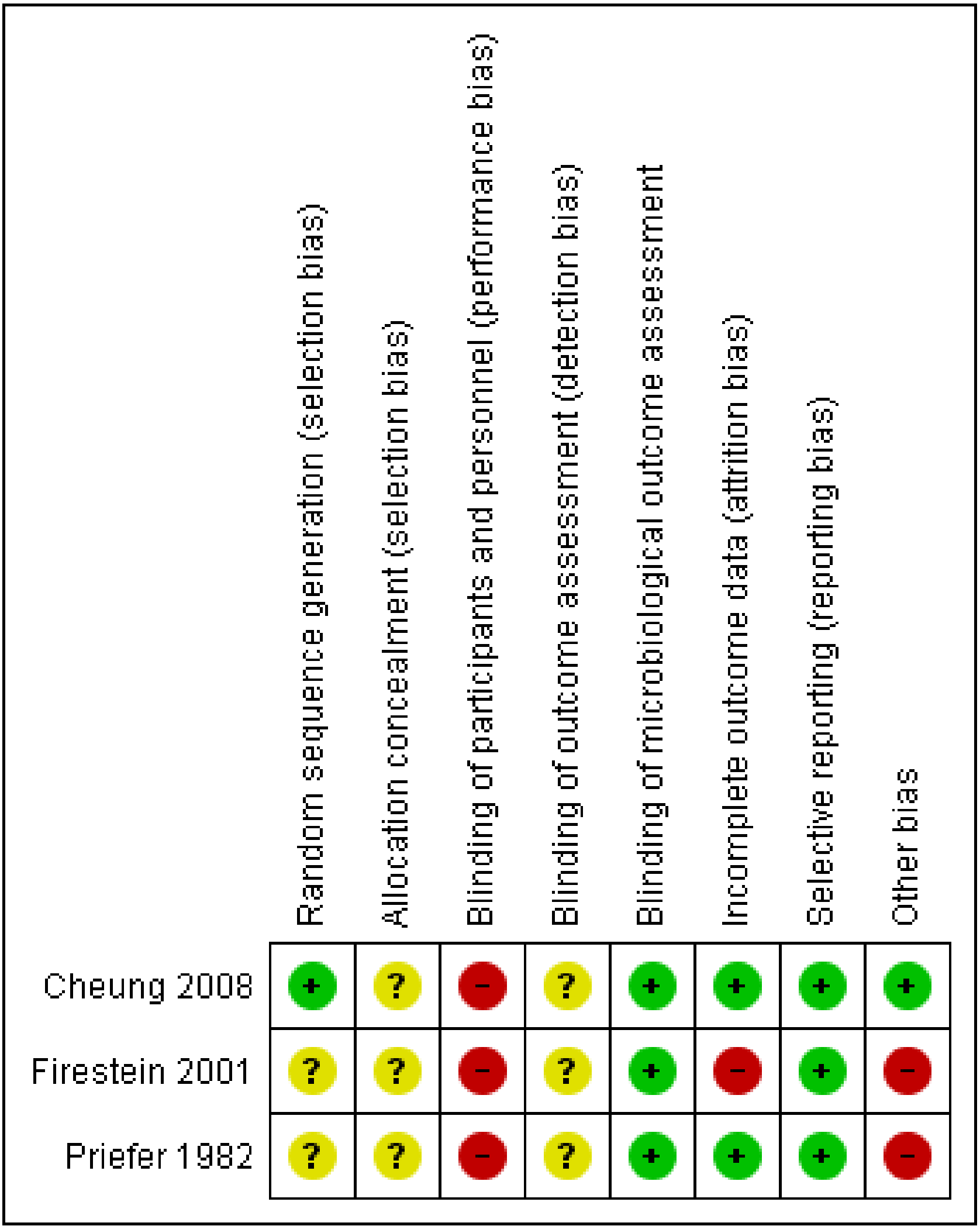




\section{Allocation}

\section{Random sequence generation}

Cheung 2008 provided details of sequence generation and was judged to be at low risk of bias. We judged the two remaining trials to be unclear (Firestein 2001; Priefer 1982)

\section{Concealment of allocation}

Methods of allocation concealment were inadequately described in all three trials and we judged them to be unclear (Cheung 2008; Firestein 2001; Priefer 1982)

\section{Blinding}

Blinding of participants and personnel in two studies are not described and are assumed to be impossible due to the nature of the interventions (Firestein 2001; Priefer 1982).

Blinding participants in one study to their method of periurethral cleansing would be possible, but is not described and therefore assumed not to occur (Cheung 2008). Additionally, this study provides no information on blinding of personnel. We assumed the outcomes in these studies were reported by the same unblinded personnel administering the intervention and they are therefore also classed as high risk.

Microbiological outcomes for the three studies are classed as low risk, as we assumed microbiologists analysing urine cultures to be blind to participants.

\section{Incomplete outcome data}

We judged two studies to be at low risk of bias (Cheung 2008; Priefer 1982). We judged Firestein 2001 to be at high risk of bias for this domain.

\section{Selective reporting}

All three trials reported all outcomes intended to be investigated by the trial and have been classed as low risk. Priefer 1982 does not report microbiological outcome, but this was not possible as urine cultures were not taken during this trial. Firestein 2001 reports incidence of CAUTI in the two groups, but not number of CAUTIs per subject over the time period.

\section{Other potential sources of bias}

We classed two studies as high risk for other areas of bias. In one study, the participants were all male (Priefer 1982). This was unavoidable due to the nature of the study setting and this could have an impact on the outcome and therefore it was judged to be high risk. There is also a wide age range in participants. In the other study, there is a calculation error, inconsistent data and a positive urine culture is not defined (Firestein 2001). We tried to contact the author but did not receive any response.

\section{Effects of interventions}

See: Summary of findings for the main comparison Monthly \& PRN catheter replacement versus PRN catheter replacement for replacing long-term indwelling urinary catheters in adults; Summary of findings 2 Antibiotics at time of replacement versus no antibiotics at time of replacement for replacing long-term indwelling urinary catheters in adults; Summary of findings 3 Sterile water versus $0.05 \%$ chlorohexidine gluconate for periurethral cleansing during replacement for replacing long-term indwelling urinary catheters in adults

\section{One interval versus another interval between catheter replacement}

One small trial found that replacing the catheter monthly as well as when clinically indicated resulted in fewer symptomatic CAUTIs than replacing the catheter monthly (RR $0.35,95 \% \mathrm{Cl} 0.13$ to 0.95 ; very low quality evidence; Analysis 1.1) (Priefer 1982). However, when expressed as number of symptomatic CAUTIs per subject over the six months, there was no significant difference between the two interventions. Participants in the 'monthly as well as clinically indicated' group required more catheter replacements but fewer irrigations than those in the clinically indicated group. However, the trial was too small (hence under-powered) to be reliable.

\section{Antibiotic prophylaxis versus no prophylaxis at the time of catheter replacement}

One small trial found that there was no statistically significant difference in incidence of positive urine culture between giving $1 \mathrm{~g}$ of intravenous meropenem 30 minutes before catheter replacement and no antibiotic: (i) 3 days after replacement (RR 0.95, $95 \% \mathrm{Cl} 0.80$ to 1.13 ); (ii) 7 days after replacement (RR $0.91,95 \% \mathrm{Cl}$ 0.79 to 1.04 ); (iii) 14 days after replacement (RR $0.94,95 \% \mathrm{Cl} 0.85$ to 1.04 ); or (iv) 28 days after replacement (RR $0.94,95 \% \mathrm{Cl} 0.84$ to 1.05 ; Analysis 2.1) (Firestein 2001). Additionally, there was no statistically significant difference in incidence of infection including urosepsis, soft tissue, pneumonia and unknown infection (RR 1.41, 95\% Cl 0.55 to 3.65; Analysis 2.2); bacteraemia (Analysis 2.3); or death (RR $2.12,95 \% \mathrm{Cl} 0.20$ to 22.30 ; very low quality evidence; Analysis 2.4 ) between the two groups. However, the trial was too small (hence under-powered) to be reliable.

\section{Replacing catheter versus other policy e.g. washouts}

No trials were identified that addressed this comparison.

\section{Replacing in home environment versus clinical environment}

No trials were identified that addressed this comparison.

\section{Clean versus aseptic technique for replacing catheter}

No trials were identified that addressed this comparison.

\section{Cleaning solution A versus cleaning solution B}

There was also no statistically significant difference in incidence of symptomatic CAUTI up to 14 days after replacement (Analysis 3.1). However, the trial was too small (hence under-powered) to be reliable. One small trial found that there was no statistically significant difference in rates of asymptomatic bacteruria between conventional $0.05 \%$ chlorhexidine gluconate $(\mathrm{CHG})$ or sterile water periurethral cleansing solutions (i) 0 days after replacement (RR not estimable; $95 \% \mathrm{Cl}$ not estimable), (ii) 7 days after replacement (RR $0.80,95 \% \mathrm{Cl} 0.42$ to 1.52 ), (iii) 14 days after replacement (RR 0.91 , $95 \% \mathrm{Cl} 0.66$ to 1.24 ; Analysis 3.2) (Cheung 2008).

\section{Lubricant A versus lubricant $B$ or no lubricant}

No trials were identified that addressed this comparison. 


\section{Patient versus carer versus health professional performing} the catheter replacement procedure

No trials were identified that addressed this comparison.

\section{DISCUSSION}

\section{Summary of main results}

We identified three trials eligible for inclusion in this review (Cheung 2008; Firestein 2001; Priefer 1982). All the included trials were small and under-powered with inadequate reporting to permit judgement.

There was insufficient evidence to indicate that there was a lower incidence of symptomatic UTI in people whose catheter was replaced both monthly and when clinically indicated (RR $0.35,95 \%$ $\mathrm{Cl} 0.13$ to 0.95 ; very low quality evidence) compared to only when clinically indicated,

There was not enough evidence to assess the effect of antibiotic prophylaxis on reducing: positive urine cultures at 7 days (RR 0.91 , $95 \% \mathrm{Cl} 0.79$ to 1.04 ); infection (RR $1.41,95 \% \mathrm{Cl} 0.55$ to 3.65 ); or death (RR 2.12, $95 \% \mathrm{Cl} 0.20$ to 22.30 ; very low quality evidence).

There was no statistically significant difference in the incidence of asymptomatic bacteruria at 7 days (RR $0.80,95 \% \mathrm{Cl} 0.42$ to 1.52 ) between participants receiving water or chlorhexidine solution for periurethral cleansing at the time of catheter replacement. However, none of the 16 participants developed a symptomatic catheter-associated urinary tract infection (CAUTI) at day 14.

Main results are summarised in Summary of findings for the main comparison; Summary of findings 2; Summary of findings 3

\section{Overall completeness and applicability of evidence}

None of the trials addressed the following comparisons: (i) replacing catheter versus other policy e.g. washouts, (ii) replacing in home environment versus clinical environment, (iii) clean versus aseptic technique for replacing catheter, (iv) lubricant $A$ versus lubricant $B$ or no lubricant, and (v) patient versus carer versus health professional performing the catheter replacement procedure. As for the policies that have been studied in this review, there are several areas of incompleteness. Two out of three studies report rates of CAUTI, an important clinical outcome. However, all the trials were small and the results were imprecise. The trials did not report outcomes such as cost, participant satisfaction, quality of life and other adverse effects such as encrustation. If a policy can be shown to be favourable in relation to these additional outcomes, it would be more likely to be implemented in worldwide practice.

Each trial only explored one alternative intervention in relation to the control. Therefore there is only data on one antibiotic, one cleaning solution and one replacement timing regime. Furthermore, sub-group analysis was not carried out in any of the trials.

The settings of these studies represent likely settings where people with long-term catheters would undergo replacements: the community, a geriatric centre and a care home.

\section{Quality of the evidence}

We assessed the quality of the evidence by examining the methodology in the report of each included trial. Since the quality of effect estimates are influenced by our judgement of the quality of methodology, the standard of reporting in the included trials directly influences the size of the effect estimates.

Only one trial gave any indication as to randomisation techniques (Cheung 2008). The randomisation method is not described in any detail in the report, but we found details of it through a reference provided and there was sufficient information to award this study low risk for selection bias. None of the three included trials gave any information on blinding of participants to the intervention. Depending on the policy, blinding of participants to their intervention at the time of catheter replacement can be impossible, for example in the trial assessing different times of replacement (Priefer 1982) or giving an antibiotic (Firestein 2001). However, blinding of participants may have been possible for using different cleaning solutions but was not detailed in Cheung 2008. We scored all three trials as high risk for performance bias as, in addition to the lack of participant blinding, we found no descriptions of blinding of personnel in any of the trials.

In regard to detection bias, the three trials do not describe accurately their methods of detecting outcomes. Therefore, we do not know if the personnel assessing these outcomes are the same as the personnel who administered the intervention. We have judged all three trials to be unclear in this domain. We only found one trial to have high risk of attrition bias: this was due to the unexplained dropouts in each arm of the study (Firestein 2001). Priefer 1982 had no dropouts and Cheung 2008 describes dropouts in detail so we judged these studies to have low risk for attrition bias.

One study has some calculation errors in its results as well as discrepancy between different areas of the report (Firestein 2001). We tried to contact the authors of this study for clarification. While we have no clarification, this study has been classed as high risk for other bias.

GRADE quality of evidence was very low for all the assessed outcomes.

\section{Potential biases in the review process}

We searched the relevant databases with no language restriction imposed. We acknowledge that these databases may not contain all the trials that could have potentially been included in this review.

\section{Agreements and disagreements with other studies or reviews}

Current guidelines on policies regarding long-term urinary catheters show considerable variation regarding this common clinical situation. Most of the available guidance comes from documents that do not specifically address policies with regard to urinary catheters but deal with conditions where long-term catheterisation might be necessary (Gould 2009; Grabe 2015; NICE Clinical Guideline CG97 2010; NICE Clinical Guideline CG139 2012; NICE Clinical Guideline CG148 2012; Saskatchewan Guidelines 2013). Guidelines are often unclear as to whether the comments with regard to use of long-term catheters are more widely applicable. 


\section{Timing of replacement of catheters}

Existing guidelines take one or more of five different approaches with regard to the replacement of long-term catheters:

1. Most guidelines recommend that catheters should be changed when there is either infection or obstruction (ANZUNS Guideline 2013; Gould 2009; NICE Clinical Guideline CG139 2012; Saskatchewan Guidelines 2013). This is the approach taken by the CDC Guideline on Catheter Associated Urinary Tract Infections that makes a Category II recommendation (implying a weak recommendation) (Gould 2009).

2. In contrast the EAU guideline on Urinary Infections recommends that change should be scheduled in anticipation of obstruction presumably based on previous need for change (Grade B, not based on randomized controlled trials) (Grabe 2015). Such a patient-centric approach is also recommended by the NICE Guideline (NICE Clinical Guideline CG139 2012).

3. A third approach has been to recommend that catheter changes should additionally be guided by the manufacturer's instruction (ANZUNS Guideline 2013; NICE Clinical Guideline CG139 2012). Presumably this would imply usage for the maximum duration that the manufacturer allows.

4. A fourth approach has been taken by two guidelines that refer to specific durations. The UK Royal Cornwall Hospitals NHS Guidance recommends that catheters could be left in place for up to 12 weeks while recognising that this might not always be feasible (Royal Cornwall Hospitals NHS Trust 2015).

5. In contrast the NICE Guideline on Urinary Incontinence in Neurological Disease states that recurrent block occurring before six weeks should be regarded as a red flag and one must reassess for secondary problems (NICE Clinical Guideline CG1482012). Clearly, catheters are ordinarily expected to remain in situ without change for a longer duration than that. The final approach is a conspicuous lack of any comment on this subject in a guideline where one would ordinarily have expected guidance (NICE Clinical Guideline CG97 2010).

\section{Cleaning and antibiotic policies while changing catheters}

1. The UK Royal Cornwall Hospitals Guideline states that cleaning the meatus with saline is suitable since there is no evidence of benefit with antiseptic solutions but makes no mention regarding use of antibiotic prophylaxis during catheter change (Royal Cornwall Hospitals NHS Trust 2015).

2. The Guidelines for the Prevention and Treatment of Urinary Tract Infections (UTIs) in Continuing Care Settings from the Canadian Saskatchewan Government recommends against the use of prophylaxis during catheter change (Saskatchewan Guidelines 2013).

3. Two different NICE Guidelines recommend selective use of antibiotics only in those individuals with a history of recurrent infection during catheter change or on occasions when there has been trauma during catheter change (NICE Clinical Guideline CG139 2012; NICE Clinical Guideline CG148 2012).

4. The EAU Guideline on Urinary Infections recommends against screening for asymptomatic bacteriuria before catheter change (Level of evidence 4, based on expert opinion) (Grabe 2015). The CDC Guideline makes a strong recommendation against the use of prophylactic antibiotics but it is unclear whether the guideline is referring to continued use of prophylaxis in people with on- going long-term catheters or whether this refers to prophylaxis only during catheter replacement (Gould 2009).

The need for additional research on use of single dose antibiotic prophylaxis has also been noted (NICE Clinical Guideline CG139 2012).

\section{AUTHORS' CONCLUSIONS}

\section{Implications for practice}

There is insufficient evidence to support catheter replacement monthly as well as when clinically indicated compared to only when clinically indicated. Further research with a larger number of participants could turn an insignificant reduction in symptomatic CAUTIs in the monthly replacement group to a significant reduction. It is unclear which policy is more favourable economically, as performing monthly replacements in addition to replacements when clinically indicated incurs more replacements, but less irrigations. As these figures were also insignificant further research is needed, particularly including the need for treatment of any symptomatic CAUTI.

There is not enough evidence to suggest whether antibiotics should be used at catheter replacement in patients with longterm catheters. However, not all variants of this intervention or outcomes have been assessed.

There is not enough evidence to suggest whether sterile water is as effective as $0.05 \% \mathrm{CHG}$ solution for periurethral cleansing between catheter replacements for reducing rates, and delaying onset, of bacteruria and symptomatic CAUTIs. However, other factors such as patient comfort remain unexplored. A formal economic analysis should be performed to determine whether this is a more costeffective approach.

\section{Implications for research}

Randomised controlled trials with higher numbers of participants and of higher quality are required in order to make recommendations for changing policies for replacing long-term catheters. Further research into the areas studied by the trials featured in this review would help strengthen the evidence to support their conclusions. Different types of antibiotics, different cleaning solutions and different periods between replacements could also be studied in addition to the interventions described in this protocol where no trials were found. Future research should aim to explore additional outcomes to asymptomatic bacteruria and symptomatic CAUTI such as participant satisfaction and costeffectiveness. A validated questionnaire should be developed for assessing participant satisfaction and quality of life measures in order to reduce heterogeneity across trials. It is also important to identify which of these outcomes not yet studied are most crucial to decision making regarding policies for replacing longterm catheters in order to guide future research. Sub-group analysis would give valuable data as to whether certain policies are more effective in sub-groups such as females or younger participants. We did not identify any long-term follow-up data. It is paramount that future trials report long-term follow-up data as this is also valuable evidence. 


\section{ACK N OWLEDGEMENTS}

We would also like to thank the following Cochrane Incontinence editorial base staff members for their help and support with this review: Cathryn Glazener, Sheila Wallace, Mandy Fader, Peter Herbison and Suzanne Macdonald. The review authors are grateful to Toby Lasseron for his advice. The review authors are thankful to Dr Beverly Priefer for responding to our query about Priefer 1982. 


\section{RE F E R E N C E S}

\section{References to studies included in this review}

Cheung 2008 \{published data only\}

Cheung K, Leung P, Wong YC, To OK, Yeung YF, Chan MW, et al. Water versus antiseptic periurethral cleansing before catheterization among home care patients: a randomized controlled trial. American Journal of Infection Control 2008;36(5):375-80. [sr-incont32160]

\section{Firestein 2001 \{published data only\}}

Firestein M. Can antibiotic use during routine replacement of long-term urinary catheter prevent bacteriuria?. Infectious Diseases in Clinical Practice 2001;10(3):133-5. [sr-incont18037]

Priefer 1982 \{published data only\}

Priefer BA, Duthie EH Jr, Gambert SR. Frequency of urinary catheter change and clinical urinary tract infection. Study in hospital-based, skilled nursing home. Urology 1982;20(2):141-2. [sr-incont7556]

\section{References to studies excluded from this review}

Airaksinen 1979 \{published data only\}

Airaksinen P, Sinkkonen S, Bolodin M, Jauhiainen R. [Clinical study of patients with indwelling catheters]. [Finnish]. Duodecim 1979;95(4):164-70.

\section{Andersson 1986 \{published data only\}}

Andersson $\mathrm{H}$. A double-blind randomized comparison of the effect and tolerance of Varidase versus saline when instilled in the urinary bladder in patients with catheter problems. Journal of International Medical Research 1986;14(2):91-4.

\section{Bach 1990 \{published data only\}}

Bach D, Hesse A, Prange $\mathrm{CH}$. Prevention of incrustations and urinary tract infections during transurethral continuous catheterization [German]. Therapiewoche Urologie Nephrologie 1990;2(1):25-32.

\section{Bergqvist 1979 \{published data only\}}

Bergqvist D, Hedelin H, Stenstrom G, Stahl A. [Clinical evaluation of Foley catheters]. [Swedish]. Lakartidningen 1979;76(15):1416-8.

\section{Boccola 2011 \{published data only\}}

Boccola MA, Sharma A, Taylor C, Wong LM, Travis D, Chan S. The infusion method trial of void vs standard catheter removal in the outpatient setting: a prospective randomized trial. BJU International 2011;107(Suppl s3):43-6.

\section{Bruun 1978 \{published data only\}}

Bruun JN, Digranes A. Bladder irrigation in patients with indwelling catheters. Scandinavian Journal of Infectious Diseases 1978;10(1):71-4.

\section{Cai 2014 \{published data only\}}

Cai T, Caola I, Tessarolo F, Piccoli F, D'Elia C, Caciagli P, et al. Solidago, orthosiphon, birch and cranberry extracts can decrease microbial colonization and biofilm development in indwelling urinary catheter: a microbiologic and ultrastructural pilot study. World Journal of Urology 2014;32(4):1007-14. [srincont70338]

\section{Carapeti 1996 \{published data only\}}

Carapeti EA, Andrews SM, Bentley PG. Randomised study of sterile versus non-sterile urethral catheterisation [published erratum appears in Annals of the Royal College of Surgeons of England 1996 May;78(3 Pt 1):167]. Annals of the Royal College of Surgeons of England 1996;78(1):59-60.

\section{Chancellor 1994 \{published data only\}}

Chancellor MB, Rivas DA, Abdill CK, Karasick S, Ehrlich SM, Staas WE. Prospective comparison of external sphincter balloon dilatation and prosthesis placement with external sphincterotomy in spinal cord injured men. Archives of Physical Medicine \& Rehabilitation 1994;75(3):297-305.

\section{Christensen 1983 \{published data only\}}

Christensen MG, Thorup J, Walter S, Vejlsgaard R, Selmer J, Geerdsen JP. Intermittent drainage of the bladder in patients with indwelling catheters. A controlled study of the occurrence of bacteriuria following after Cystomat without irrigation. [Danish]. Ugeskrift for Laeger 1983;145(1):22-3.

\section{Chung 2007 \{published data only\}}

Chung C, Chu M, Paoloni R, O'Brien MJ, Demel T. Comparison of lignocaine and water-based lubricating gels for female urethral catheterization: a randomized controlled trial. Emergency Medicine Australasia 2007;19(4):315-9.

\section{Clark 1973 \{published data only\}}

Clark LW. Neomycin in the prevention of postcatheterization bacteriuria. Medical Journal of Australia 1973;1(21):1034-6.

\section{Classen 1991a \{published data only\}}

Classen DC, Larsen RA, Burke JP, Alling DW, Stevens LE. Daily meatal care for prevention of catheter-associated bacteriuria: results using frequent applications of polyantibiotic cream. Infection Control \& Hospital Epidemiology 1991;12(3):157-62.

Cleland 1971 \{published data only\}

Cleland V, Cox F, Berggren H, MacInnis MR. Prevention of bacteriuria in female patients with welling catheters. Nursing Research 1971;20(4):309-18.

\section{Cornia 2003 \{published data only\}}

Cornia PB, Amory JK, Fraser S, Saint S, Lipsky BA. Computerbased order entry decreases duration of indwelling urinary catheterization in hospitalized patients. American Journal of Medicine 2003;114(5):404-7.

Darouiche 2005 \{published data only\}

* Darouiche RO, Thornby JI, Cerra-Stewart C, Donovan WH, Hull RA. Bacterial interference for prevention of urinary tract infection: a prospective, randomized, placebo-controlled, double-blind pilot trial.[see comment]. Clinical Infectious Diseases 2005;41(10):1531-4. 
NCT00037921, Darouiche R. UTI Prophylaxis Using Bacterial Interference Following SCl. http://clinicaltrials.gov/show/ NCT00037921 2001.

\section{Darouiche 2011 \{published data only\}}

* Darouiche RO, Green BG, Donovan WH, Chen D, Schwartz M, Merritt J, et al. Multicenter randomized controlled trial of bacterial interference for prevention of urinary tract infection in patients with neurogenic bladder. Urology 2011;78(2):341-6.

NCT00309114, Darouiche R, Trautner B. Prevention of UTI in Persons With Spinal Cord Injury. http://clinicaltrials.gov/show/ NCT003091142004.

\section{Darouiche 2014 \{published data only\}}

* Darouiche RO, Al Mohajer M, Siddiq DM, Minard CG. Short versus long course of antibiotics for catheter-associated urinary tract infections in patients with spinal cord injury: a randomized controlled noninferiority trial. Archives of Physical Medicine \& Rehabilitation 2014;95(2):290-6.

NCT00732238, Darouiche RO. Multifaceted Treatment of Catheter-related Urinary Tract Infection. http:// clinicaltrials.gov/show/NCT00732238 2007.

\section{Davies 1987 \{published data only\}}

Davies AJ, Desai HN, Turton S, Dyas A. Does instillation of chlorhexidine into the bladder of catheterized geriatric patients help reduce bacteriuria?. Journal of Hospital Infection 1987;9(1):72-5

\section{Eddeland 1983 \{published data only\}}

Eddeland A, Hedelin H. Effects of allopurinol (Zyloric) in patients with long-term indwelling urethral catheters. Journal of International Medical Research 1983;11(2):116-9.

\section{Ehrenkranz 1991 \{published data only\}}

Ehrenkranz NJ, Alfonso BC. Failure of bland soap handwash to prevent hand transfer of patient bacteria to urethral catheters. Infection Control \& Hospital Epidemiology 1991;12:654-62.

\section{Eid 1995 \{published data only\}}

Eid Y, Sevilla D, Akerman A, Aisen ML. Reexamination of neurogenic bladder management in myelopathy. Journal of Neurologic Rehabilitation 1995;9(2):124.

\section{Flack 1993 \{published data only\}}

Flack S. Finding the best solution... encrustation of indwelling urethral catheters... how effective are bladder-washout solutions. Nursing Times 1993;89(11):68, 70, 77.

\section{Fryklund 1991 \{published data only\}}

Fryklund B, Pettersson B, Svenson G, Burman LG. [A closed system for bladder drainage via an indwelling catheter reduces the risks of bacteriuria]. [Swedish]. Lakartidningen 1991;88(9):738, 740-1.

\section{Hayward 2012 \{published data only\}}

Hayward C. Pilot investigation of the effect of the Memokath 028 Prostate $\subsetneq$ stent on quality of life in patients with urethral obstruction a comparison with long term catheter. http:// isrctn.com/ISRCTN33583715 2012.

\section{Lee 2015 \{published data only\}}

Lee K-C, Chao Y-F, Wang Y-M, Lin P-C. A nurse-family partnership intervention to increase the self-efficacy of family caregivers and reduce catheter-associated urinary tract infection in catheterized patients. International Journal of Nursing Practice 2015;21(6):771-9. [sr-incont72604]

\section{Li 2014 \{published data only\}}

$\mathrm{Li} \mathrm{HJ,} \mathrm{Cao} \mathrm{XJ.} \mathrm{A} \mathrm{prospective} \mathrm{randomized} \mathrm{comparative} \mathrm{study} \mathrm{on}$ effects in preventing urinary tract infection between Intelligent urinary bladder monitoring device and conventional urinary catheter in patients with voiding dysfunction caused by spinal cord injury. http://www.chictr.org.cn/showproj.aspx? proj=10090 2014.

\section{Moore 2004 \{published data only\}}

Moore K, Hunter K, McGinnis R, Chobanuk J, Bascu C, Puttagunta $\mathrm{L}$, et al. Extending the life of long term indwelling catheters: an RCT of catheter flush with saline or acidic solution vs standard care (Abstract number 66). Neurourology \& Urodynamics 2007;26(5):685.

Moore K, Puttagunta L, Voaklander D, McGinnis R, Fader M, Getliffe K, et al. Long term indwelling catheters: an RCT of catheter flush vs. standard care (Abstract number 2423). Journal of WOCN 2008;35(3S Suppl):S65.

* Moore KN, Hunter KF, McGinnis R, Bacsu C, Fader M, Gray M, et al. Do catheter washouts extend patency time in longterm indwelling urethral catheters? A randomized controlled trial of acidic washout solution, normal saline washout, or standard care. Journal of Wound, Ostomy, \& Continence Nursing 2009;36(1):82-90.

\section{Nalinthip 1996 \{published data only\}}

Nalinthip T, et al. Urinary tract infection in self-catheterisation compared to nurse-catheterisation for bladder training in patients with spinal cord lesion (Abstract). Srinagarind Medical Journal 1996;11(4):345

\section{NCT01785966, 2013 \{published data only\}}

NCT01785966, Cavalcanti AB. Checklist During Multidisciplinary Daily Visits and Clinician Prompting for Reduction of Mortality in Intensive Care Units: A Cluster Randomized Trial. http:// clinicaltrials.gov/show/NCT01785966 2013.

\section{NCT01797146, 2013 \{published data only\}}

NCT01797146, Rattanaumpawan P. Effectiveness of Catheter Reminder and Evaluation (CARE) Program in Reducing the Catheter-day and Prevention of Catheter-associated Infections. http://clinicaltrials.gov/show/NCT01797146 2013.

\section{NCT02196987, 2014 \{published data only\}}

NCT02196987, Stav K. Pain Level During Male Urethral Catheterisation - Does Patient Attempted Urination During Catheterisation Reduce Pain? A Prospective Randomized Study. http://clinicaltrials.gov/show/NCT02196987 2014. 
Norton 1987 \{published data only\}

Norton P. Urethral mini-catheter revisited. Proceedings of the International Continence Society (ICS), 17th Annual Meeting, 1987 Sep 2-5, Bristol, UK 1987:146-7.

\section{Oberst 1981 \{published data only\}}

Oberst MT, Graham D, Geller NL, Stearns MW Jr, Tiernan E. Catheter management programs and postoperative urinary dysfunction. Research in Nursing \& Health 1981;4(1):175-81.

\section{Obolensky 1975 \{published data only\}}

Obolensky W, Hubner $\mathrm{H}$. When should the medicamentous prevention of catheter infection be started? [German] (Abstract number 222). Archiv fur Gynakologie 1975;219(1-4):240-1.

\section{Pickard 1996 \{published data only\}}

Pickard WG, Grundy DJ. A comparison of two methods of sterile urethral catheterisation in spinal cord injured adults. Paraplegia 1996;34(1):30-3.

\section{Platt 1983 \{published data only\}}

Platt R, Polk BF, Murdock B, Rosner B. Reduction of mortality associated with nosocomial urinary tract infection. Lancet 1983;1(8330):893-7.

\section{Raz 2000 \{published data only\}}

Raz R, Schiller D, Nicolle LE. Chronic indwelling catheter replacement before antimicrobial therapy for symptomatic urinary tract infection. Journal of Urology 2000;164(4):1254-8. [sr-incont15653]

\section{Reid 1982 \{published data only\}}

Reid RI, Webster O, Pead PJ, Maskell R. Comparison of urine bag-changing regimens in elderly catheterised patients. Lancet 1982;2(8301):754-6.

\section{Samimi 2010 \{published data only\}}

Samimi Gh, Ezzati Zh, Sarokhani MR, Mosalii SS, Mehrabi Y. Effects of bladder irrigation with chlorhexidine and normal saline on prevention of bacteriuria in patient with foley catheter [Farsi]. Journal of Nursing \& Midwifery 2010;20(70):57.

\section{Savage 1982 \{published data only\}}

Savage JE, Phillips B, Lifshitz S, et al. Bacteriuria in closed bladder drainage versus continuous irrigation in patients undergoing intracavitary radium for treatment of gynecologic cancer. Gynecologic Oncology 1982;13:26-30.

\section{Schneeberger 1992 \{published data only\}}

Schneeberger PM, Vreede RW, Bogdanowicz JF, van Dijk WC. A randomized study on the effect of bladder irrigation with povidone-iodine before removal of an indwelling catheter. Journal of Hospital Infection 1992;21(3):223-9.

\section{Shimpuku 2013 \{published data only\}}

Shimpuku G. The effect of lidocaine jelly for pain of urinary catheter. http://www.umin.ac.jp/ctr/index.htm 2013. in males: a randomized controlled trial. Academic Emergency Medicine 2004;11(6):703-6.

Sperling 2014 \{published data only\}

Sperling H, Eisenhardt A, Mumperow E, Gralla O, Lummen G, Seidali $\mathrm{K}$, et al. Investigation of the use of triclosan in patients with indwelling catheters: A randomized, double blind, multicenter, placebo-controlled clinical study. [German]. Der Urologe 2014;53(10):1512-7.

\section{Sweet 1985 \{published data only\}}

Sweet DE, Goodpasture HC, Holl K, Smart S, Alexander H, Hedari A. Evaluation of $\mathrm{H} 2 \mathrm{O} 2$ prophylaxis of bacteriuria in patients with long-term indwelling Foley catheters: a randomized controlled study. Infection Control 1985;6(7):263-6.

Taweesangsuksalul 2005 \{published data only\} Taweesangsuksalul R, Tamnanthong N, Hanpanich K, Chobchuen R, Kirdpon W. Effect of aloe vera gel for lubrication on urethral catheterization. Journal of Thai Rehabilitation Medicine 2005;15(2):113-8.

\section{Webster 2000 \{published data only\}}

Webster J, Hood R, Burridge C, Cave D, Mastin H. Pilot study - the use of antiseptic verses tap water for urethral preparation prior to insertion of urinary catheters: The IDS Study. Unpublished protocol summary on file 2000.

\section{Webster 2006 \{published data only\}}

Webster J, Osborne S, Woolett K, Shearer J, Courtney M, Anderson $D$. Does evening removal of urinary catheters shorten hospital stay among general hospital patients? A randomized controlled trial. Journal of Wound, Ostomy, \& Continence Nursing 2006;33(2):156-63.

Wilde 2011 \{published data only\}

Wilde $\mathrm{MH}$. Self management in urinary catheter users. clinicaltrials.gov/ct2/show/NCT00883220 (accessed 14 September 2011).

\section{Wilde 2015 \{published data only\}} Wilde MH, McMahon JM, McDonald MV, Tang W, Wang W, Brasch J, et al. Self-management intervention for long-term indwelling urinary catheter users: randomized clinical trial. Nursing Research 2015;64(1):24-34. [sr-incont66839]

Williamson 1982 \{published data only\} Williamson ML. Reducing post-catheterization bladder dysfunction by reconditioning. Nursing Research 1982;31:28-30.

Zhao 1994 \{published data only\}

Zhao WH, Zang YF. [Research on two methods of urinary catheterization post radio frequency therapy for the patient with hypertrophy of the prostate]. Chung-Hua Hu Li Tsa Chih Chinese Journal of Nursing 1994;29(7):408-9.

\section{Siderias 2004 \{published data only\}}

Siderias J, Guadio F, Singer AJ. Comparison of topical anesthetics and lubricants prior to urethral catheterization 


\section{Additional references}

\section{ANZUNS Guideline 2013}

Australia and New Zealand Urological Nurses Society Catheterisation Guideline Working Party. Catheterisation Clinical Guidelines (version 2). http://www.anzuns.org/ wp-content/uploads/2015/03/ANZUNS-Guidelines Catheterisation-Clinical-Guidelines.pdf (accessed 6 January 2016).

Gould 2009

Gould CV, Umscheid CA, Agarwal RK, Kuntz G, Pegues DA, Healthcare Infection Control Practices Advisory Committee (HICPAC). Guideline for prevention of catheter-associated urinary tract infections 2009. http://www.cdc.gov/hicpac/pdf/ CAUTI/CAUTIguideline2009final.pdf (accessed 6 January 2016).

\section{Gould 2010}

Gould CV, Umscheid CA, Agarwal RK, Kuntz G, Pegues DA. Guideline for prevention of catheter-associated urinary tract infections 2009. Infection Control and Hospital Epidemiology 2010;31(4):319-26.

\section{Grabe 2015}

Grabe M, Bartoletti R, Bjerklund Johansen TE, Cai T, Cek M, Koves B, et al. Guidelines on Urological Infections (limited update March 2015). http://uroweb.org/wp-content/ uploads/19-Urological-infections_LR2.pdf (accessed 6 January 2016).

\section{Guyatt 2011a}

Guyatt GH, Oxman AD, Schunemann HJ, Tugwell P, Knottnerus A. GRADE guidelines: a new series of articles in the Journal of Clinical Epidemiology. Journal of Clinical Epidemiology 2011;64(4):380-2.

\section{Guyatt 2011b}

Guyatt GH, Oxman AD, Sultan S, Glasziou P, Akl EA, AlonsoCoello P, et al. GRADE guidelines: 9. Rating up the quality of evidence. Journal of Clinical Epidemiology 2011;64(12):1311-6.

\section{Guyatt 2013a}

Guyatt GH, Thorlund K, Oxman AD, Walter SD, Patrick D, Furukawa TA, et al. GRADE guidelines: 13. Preparing Summary of Findings tables and evidence profiles-continuous outcomes. Journal of Clinical Epidemiology 2013;66(2):173-83.

\section{Guyatt 2013b}

Guyatt GH, Oxman AD, Santesso N, Helfand M, Vist G, Kunz R, et al. GRADE guidelines: 12. Preparing Summary of Findings tables-binary outcomes. Journal of Clinical Epidemiology 2013;66(2):158-72.

\section{Hagen 2010}

Hagen S, Sinclair L, Cross S. Washout policies in long-term indwelling urinary catheterisation in adults. Cochrane Database of Systematic Reviews 2010, Issue 3. [DOI: 10.1002/14651858.CD004012.pub4]

\section{Higgins 2011}

Higgins JPT, Green S (editors). Cochrane Handbook for Systematic Reviews of Interventions Version 5.1.0 [updated March 2011]. The Cochrane Collaboration, 2011. Available from www.cochrane-handbook.org.

\section{Hooton 2010}

Hooton TM, Bradley SF, Cardenas DD, Colgan R, Geerlings SE, Rice JC, et al. Diagnosis, prevention, and treatment of catheterassociated urinary tract infection in adults: 2009 International Clinical Practice Guidelines from the Infectious Diseases Society of America. Clinical Infectious Diseases 2010;50(5):625-63.

\section{Jahn 2007}

Jahn P, Beutner K, Langer G. Types of indwelling urinary catheters for long-term bladder drainage in adults. Cochrane Database of Systematic Reviews 2007, Issue 10. [DOI: 10.1002/14651858.CD004997.pub3]

\section{Lusardi 2013}

Lusardi G, Lipp A, Shaw C. Antibiotic prophylaxis for short-term catheter bladder drainage in adults. Cochrane Database of Systematic Reviews 2013, Issue 7. [DOI: 10.1002/14651858.CD005428.pub2]

\section{Maki 2001}

Maki DG, Tambyah PA. Engineering out the risk for infection with urinary catheters. Emerging Infectious Diseases 2001;7(2):342-7.

\section{Moore 2007}

Moore KN, Fader M, Getliffe K. Long-term bladder management by intermittent catheterisation in adults and children. Cochrane Database of Systematic Reviews 2007, Issue 4. [DOI: 10.1002/14651858.CD006008.pub2]

\section{NICE Clinical Guideline CG139 2012}

National Clinical Guideline Centre. Healthcare-associated infections: prevention and control in primary and community care. NICE Clinical Guideline CG139. www.nice.org.uk/guidance/ cg139 (accessed 6 January 2016).

\section{NICE Clinical Guideline CG148 2012}

National Clinical Guideline Centre, National Institute for Health and Clinical Excellence. Urinary incontinence in neurological disease: Management of lower urinary tract dysfunction in neurological disease. NICE Clinical Guideline CG148. http:// www.nice.org.uk/guidance/cg148/evidence (accessed 6 January 2016).

\section{NICE Clinical Guideline CG97 2010}

National Clinical Guideline Centre: Acute and Chronic Conditions. Lower urinary tract symptoms in men: management. NICE Clinical Guideline CG97. www.nice.org.uk/ guidance/cg97 (accessed 6 January 2016).

\section{Nicolle 2001}

Nicolle LE. The chronic indwelling catheter and urinary infection in long-term-care facility residents. Infection Control and Hospital Epidemiology 2001;22(5):316-21. 


\section{Niël-Weise 2005}

Niël-Weise BS, van den Broek PJ, da Silva EMK, Silva LA. Urinary catheter policies for long-term bladder drainage. Cochrane Database of Systematic Reviews 2005, Issue 3. [DOI: 10.1002/14651858.CD004201.pub3]

\section{Palka 2014}

Palka MA. Evidenced based review of recommendations addressing the frequency of changing long-term indwelling urinary catheters in older adults. Geriatric Nursing 2014;35(5):357-63.

\section{Reference Manager 2012 [Computer program]}

Thomson Reuters. Reference Manager Professional Edition Version 12. New York: Thomson Reuters, 2012.

\section{Royal Cornwall Hospitals NHS Trust 2015}

Royal Cornwall Hospitals NHS Trust Continence Action Group. RCHT Adult Urinary Catheterisation Policy v4.2. http://www.rcht.nhs.uk/DocumentsLibrary/ RoyalCornwallHospitalsTrust/Clinical/General/ UrinaryCatheterisationPolicy.pdf (accessed 5 January 2015).

\section{Saskatchewan Guidelines 2013}

Saskatchewan Infection Prevention and Control Program. Guidelines for the prevention and treatment of urinary tract infections (UTIs) in continuing care settings. http:// www.ipac-canada.org/IPAC-SASKPIC/UTI\%20Guidelines \%2019April2013.pdf (accessed 5 January 2016).

\section{Stamm 1991}

Stamm WE. Catheter-associated urinary tract infections: epidemiology, pathogenesis, and prevention. The American Journal of Medicine 1991;91(3 (Supp 2)):S65-71.

\section{Stensballe 2005}

Stensballe J, Looms D, Nielsen P N, Tvede M. Hydrophilic-coated catheters for intermittent catheterisation reduce urethral micro trauma: a prospective, randomised, participant-blinded, crossover study of three different types of catheters. European Urology 2005;48(6):978-83.

\section{Sørbye 2009}

Sørbye LW, Finne-Soveri H, Ljunggren G, Topinkova E, GarmsHomolova V, Jensdóttir $A B$, et al. Urinary incontinence and use of pads - clinical features and need for help in home care at 11 sites in Europe. Scandinavian Journal of Caring Sciences 2009;23:33-44.

\section{Wilde 2013}

Wilde MH, McDonald MV, Brasch JRN, McMahon JM, Fairbanks EMS, Shah S, Tang W, Scheid E. Long-term urinary catheter users self-care practices and problems. Journal of Clinical Nursing February 2013;22(3-4):356-67.

\section{Willson 2009}

Willson M, Wilde M, Webb ML, Thompson D, Parker D, Harwood J, et al. Nursing interventions to reduce the risk of catheter-associated urinary tract infection: part 2: staff education, monitoring, and care techniques. Journal of Wound Ostomy \& Continence Nursing 2009;36(2):137-54.

* Indicates the major publication for the study

\section{CHARACTERISTICS OF STUDIES}

Characteristics of included studies [ordered by study ID]

Cheung 2008

Methods Study design: Randomised Controlled Trial

Setting: Community nursing service centre in Hong Kong.

Study dates: Not specified

Participants

Population: People residing in one community nurse service centre in Hong Kong (living at home or in a nursing home).

Inclusion criteria: aged 18 years or older, receiving community nursing services, requiring long-term indwelling latex urinary catheter and already under community nursing service and requiring longterm catheter care for at least 1 month.

Exclusion criteria: subjects with a symptomatic urinary tract infection on the day of baseline urine collection.

Age (mean): $78.4(\mathrm{SD}=11.8)$

Number of participants:

- Eligible: 26 
Cheung 2008 (Continued)

- Randomised: 22

- Reported: 20

Dropouts (number of participants \& reasons): 4 subjects refused to participate on the day of catheter change. 2 subjects were excluded from data analysis: 1 due to urinary tract infection and 1 due to antibiotic treatment for fever.

After 7 days, 2 subjects dropped out from the intervention group because of urinary catheter removal as prescribed by a physician and were admitted to the hospital for a respiratory problem. After 14 days, 1 subject dropped out from the control group because of urinary catheter removal as prescribed by physician. 1 subject dropped out from the intervention group because of admission to the hospital for general deterioration in condition.

Interventions

Control group (12): Conventional $0.05 \%$ chlorhexidine gluconate periurethral cleansing.

Intervention group (8): Sterile water periurethral cleansing.

\section{Outcomes Symptomaic bacteruria}

14 days after catheter replacement: Control 0/9; Intervention 0/7

\section{High ( $>10^{5} \mathrm{cfu} / \mathrm{mL}$ ) urine culture colonisation count}

0 days after catheter replacement: Control $0 / 12$; Intervention 0/8

7 days after catheter replacement: Control 6/10; Intervention 6/8

14 days after catheter replacement: Control $8 / 9$; Intervention 7/7

Funding/Sponsorship No information provided.

Notes $\quad$ Randomisation method referenced as "Simon" with a link that does not work. This link does work:
http://www.bmj.com/rapid-response/2011/10/28/simple-approach-randomisation

\section{Risk of bias}

\begin{tabular}{|c|c|c|}
\hline Bias & Authors' judgement & Support for judgement \\
\hline $\begin{array}{l}\text { Random sequence genera- } \\
\text { tion (selection bias) }\end{array}$ & Low risk & $\begin{array}{l}\text { "The simple randomization method suggested by Simon was used to allocate } \\
\text { subjects to } \\
\text { either the sterile water group or the conventional } 0.05 \% \text { CHG group". }\end{array}$ \\
\hline $\begin{array}{l}\text { Allocation concealment } \\
\text { (selection bias) }\end{array}$ & Unclear risk & No information given. \\
\hline $\begin{array}{l}\text { Blinding of participants } \\
\text { and personnel (perfor- } \\
\text { mance bias) } \\
\text { All outcomes }\end{array}$ & High risk & $\begin{array}{l}\text { Nurses performed cleansing and were therefore not blind to intervention. } \\
\text { Participants may be able to sense differences between the two cleansing } \\
\text { agents and thus determine their intervention. }\end{array}$ \\
\hline $\begin{array}{l}\text { Blinding of outcome as- } \\
\text { sessment (detection bias) } \\
\text { All outcomes }\end{array}$ & Unclear risk & $\begin{array}{l}\text { "Nurses also followed the standard protocol for urine collection: all urine } \\
\text { specimens were collected through a sterile syringe into a sterile bottle to avoid } \\
\text { contamination, and the specimens were kept in a cooler and sent to the labo- } \\
\text { ratory within } 2 \text { hours". } \\
\text { No information regarding detection of CAUTI in participants. }\end{array}$ \\
\hline $\begin{array}{l}\text { Blinding of microbiologi- } \\
\text { cal outcome assessment }\end{array}$ & Low risk & $\begin{array}{l}\text { The microbiologists analysing samples are assumed to be blind to the treat- } \\
\text { ment of the participants. }\end{array}$ \\
\hline
\end{tabular}


Cheung 2008 (Continued)

Incomplete outcome data Low risk All participants who dropped out were accounted for. See Participants above. (attrition bias)

All outcomes

$\begin{array}{ll}\begin{array}{l}\text { Selective reporting (re- } \\ \text { porting bias) }\end{array} & \text { Low risk } \\ \end{array}$

Other bias Low risk Appears to be free of other sources of bias.

Firestein 2001

Study design: Randomised Controlled Trial
Setting: The Shoham Geriatric Center, Israel. A 970-bed multilevel geriatric centre
Study dates: November 1998 to August 1999.

Participants $\quad$ Population: Residents of a geriatric medical centre.

Inclusion criteria: Residents with a long-term urinary catheter.

Exclusion criteria: Urinary catheter in place for less than 4 weeks or antibiotic use within the 2-week period before enrolment.

Age (mean): $79.3+/-9.6$ years.

\section{Number of participants:}

- Eligible: Not specified.

- Randomised: Not specified.

- Reported: 70 (36 control group, 34 intervention group) with various unexplained dropouts at different points of time in outcome measures.

Dropouts (number of participants \& reasons): Not specified.

Control group (36): No antibiotic at time of catheter replacement.

Intervention group (34): $1 \mathrm{~g}$ IV Meropenam 30 minutes before catheter replacement.

Outcomes Positive urine culture

1 to 3 days after replacement: Control 32/35; Intervention 27/31

7 days after replacement: Control 35/36 ; Intervention 30/34

14 days after replacement: Control 34/34 ; Intervention 31/33

28 days after replacement: Control 28/28; Intervention 30/32

\section{Infection}

Up to 28 days after replacement: Control 6/36 ; Intervention 8/34

\section{Bacteraemia}

Up to 28 days after replacement: Control $0 / 36$; Intervention $0 / 34$

Death

Up to 28 days after replacement: Control $1 / 36$; Intervention $2 / 34$ 
Firestein 2001 (Continued)

Funding/Sponsorship No information provided.

Notes The contact person for this study was contacted regarding inconsistencies in reported results.

\section{Risk of bias}

\begin{tabular}{|c|c|c|}
\hline Bias & Authors' judgement & Support for judgement \\
\hline $\begin{array}{l}\text { Random sequence genera- } \\
\text { tion (selection bias) }\end{array}$ & Unclear risk & No information provided on randomisation techniques. \\
\hline $\begin{array}{l}\text { Allocation concealment } \\
\text { (selection bias) }\end{array}$ & Unclear risk & No information provided on allocation concealment. \\
\hline $\begin{array}{l}\text { Blinding of participants } \\
\text { and personnel (perfor- } \\
\text { mance bias) } \\
\text { All outcomes }\end{array}$ & High risk & $\begin{array}{l}\text { No information provided on blinding of participants or personnel. It is as- } \\
\text { sumed there is no blinding as the intervention is invasive. }\end{array}$ \\
\hline $\begin{array}{l}\text { Blinding of outcome as- } \\
\text { sessment (detection bias) } \\
\text { All outcomes }\end{array}$ & Unclear risk & No information provided. \\
\hline $\begin{array}{l}\text { Blinding of microbiologi- } \\
\text { cal outcome assessment }\end{array}$ & Low risk & $\begin{array}{l}\text { The microbiologists analysing samples are assumed to be blind to the treat- } \\
\text { ment of the participants. }\end{array}$ \\
\hline $\begin{array}{l}\text { Incomplete outcome data } \\
\text { (attrition bias) } \\
\text { All outcomes }\end{array}$ & High risk & $\begin{array}{l}\text { There are unexplained dropouts in each arm of the study at each time period. } \\
\text { The number of infections per subject is not reported. }\end{array}$ \\
\hline $\begin{array}{l}\text { Selective reporting (re- } \\
\text { porting bias) }\end{array}$ & Low risk & $\begin{array}{l}\text { All outcomes intended to be investigated were reported. However, the study } \\
\text { protocol was not assessed. }\end{array}$ \\
\hline Other bias & High risk & $\begin{array}{l}\text { A positive urine culture is not defined and therefore the cut-off for a positive } \\
\text { outcome may be different from similar studies. There are calculation errors in } \\
\text { the results section. }\end{array}$ \\
\hline
\end{tabular}

Priefer 1982

Methods

Study design: Randomised Controlled Trial

Setting: Veterans Administration hospital-based nursing home in Wisconsin.

Study dates: "Over a 6 month period"

Participants

Population: Males in a Veterans Administration hospital-based nursing home with long-term indwelling urethral catheters.

Inclusion criteria: Not specified.

Exclusion criteria: Transfer to a hospital for acute problems other than those related to the urinary tract.

Age (mean): Control group: $77.1+/-16.3$; Intervention group: $83.4+/-7.9$ years

\section{Number of participants}

- Eligible: Not specified 
Priefer 1982 (Continued)

- Randomised: Not specified

- Reported: 17 (7 in control group, 10 in intervention group).

Dropouts (number of participants \& reasons): Not specified.

Interventions

Control group (7): Catheter replacement only when indicated by infection (as defined in the study) or obstruction.

Intervention group (10): Catheter replacement monthly as well as when indicated by infection (as defined in the study) or obstruction.

Outcomes

\section{Development of symptomatic CAUTI in 6-month period:}

Control $6 / 7$; Intervention $3 / 10$

(Also expressed as number per subject: Control $1.0+/-0.6$; Intervention $0.4+/-0.7$ )

Number of catheter replacements:

(Expressed as number per subject) Control $0.64+/-0.4$; Intervention $1.3+/-0.6$

\section{Number of catheter irrigations:}

(Expressed as number per subject) Control $1.5+/-2.3$; Intervention $0.9+/-1.7$

\section{Organism found at time of CAUTI:}

No difference. Data not available.

\begin{tabular}{ll}
\hline Funding/Sponsorship & Not specified. \\
\hline Notes & $\begin{array}{l}\text { Inconsistency between results table and results in text for number of irrigations. The results in the text } \\
\text { are correct (clarified with the author 27.06.15). }\end{array}$ \\
\hline
\end{tabular}

\section{Risk of bias}

\begin{tabular}{lll}
\hline Bias & Authors' judgement & Support for judgement \\
\hline $\begin{array}{l}\text { Random sequence genera- } \\
\text { tion (selection bias) }\end{array}$ & Unclear risk & No information provided on randomisation techniques \\
\hline $\begin{array}{l}\text { Allocation concealment } \\
\text { (selection bias) }\end{array}$ & Unclear risk & No information provided on allocation concealment. \\
\hline $\begin{array}{l}\text { Blinding of participants } \\
\text { and personnel (perfor- } \\
\text { mance bias) } \\
\text { All outcomes }\end{array}$ & High risk & Participants and personnel are assumed not to be blinded to intervention. \\
\hline $\begin{array}{l}\text { Blinding of outcome as- } \\
\text { sessment (detection bias) } \\
\text { All outcomes }\end{array}$ & Unclear risk & $\begin{array}{l}\text { No information given on who was responsible for recording number of irriga- } \\
\text { tions or replacements. }\end{array}$ \\
\hline $\begin{array}{l}\text { Blinding of microbiologi- } \\
\text { cal outcome assessment }\end{array}$ & Low risk & $\begin{array}{l}\text { The microbiologists analysing samples are assumed to be blind to the treat- } \\
\text { ment of the participants. }\end{array}$ \\
\hline $\begin{array}{l}\text { Incomplete outcome data } \\
\text { (attrition bias) } \\
\begin{array}{l}\text { All outcomes } \\
\hline\end{array}\end{array}$ & Low risk & $\begin{array}{l}\text { There were no dropouts and there is no missing data. Some outcomes are ex- } \\
\text { pressed as number per subject, however this is appropriate. }\end{array}$ \\
\hline
\end{tabular}


Priefer 1982 (Continued)

$\begin{array}{ll}\begin{array}{l}\text { Selective reporting (re- } \\ \text { porting bias) }\end{array} & \text { Low risk outcomes intended to be investigated were reported. However, the study } \\ \text { protocol was not assessed. }\end{array}$

porting bias)

High risk

This trial only studied male participants. There was a wider range in age of participants compared to similar studies.

Characteristics of excluded studies [ordered by study ID]

\begin{tabular}{|c|c|}
\hline Study & Reason for exclusion \\
\hline Airaksinen 1979 & Deals with bladder irrigation and does not address replacement of long-term catheters. \\
\hline Andersson 1986 & Does not compare washout to replacement. \\
\hline Bach 1990 & Washout policy. Not related to replacement of long-term catheters. \\
\hline Bergqvist 1979 & Compares types of catheters. \\
\hline Boccola 2011 & Not related to replacement of long-term catheters. \\
\hline Bruun 1978 & Compares types of intermittent irrigation. Does not address replacement. \\
\hline Cai 2014 & $\begin{array}{l}\text { Intervention not relevant. The study is not about the policies for replacing long-term indwelling uri- } \\
\text { nary catheters. }\end{array}$ \\
\hline Carapeti 1996 & $\begin{array}{l}\text { Erratum message to authors of RCT which should not be included as it is not about long-term } \\
\text { catheters. }\end{array}$ \\
\hline Chancellor 1994 & Not an RCT and does not study catheters. \\
\hline Christensen 1983 & Deals with short-term catheters. \\
\hline Chung 2007 & Intervention is related to first time catheterisation and temporary catheters. \\
\hline Clark 1973 & Participants' indwelling catheters are post-operative and not long-term. \\
\hline Classen 1991a & Policy is not related to replacing indwelling catheters in this study. \\
\hline Cleland 1971 & Does not address policies for replacing long term catheters. \\
\hline Cornia 2003 & Does not address replacement of long term-catheters. \\
\hline Darouiche 2005 & Does not address replacement of long-term catheters. \\
\hline Darouiche 2011 & Intervention not relevant. The study compares HU2117 versus sterile saline. \\
\hline Darouiche 2014 & Studies policies for replacement when indicated by CAUTI, not routine replacement. \\
\hline Davies 1987 & Compares washout regimens and does not address replacement of catheter. \\
\hline Eddeland 1983 & $\begin{array}{l}\text { Participants have long-term indwelling catheters, but intervention (allopurinol vs placebo) is not } \\
\text { administered at time of replacement. This study does explore requirement for catheter change as } \\
\text { an adverse outcome, however. }\end{array}$ \\
\hline
\end{tabular}




\begin{tabular}{|c|c|}
\hline Study & Reason for exclusion \\
\hline Ehrenkranz 1991 & Not an RCT. \\
\hline Eid 1995 & Does not address catheter replacement. \\
\hline Flack 1993 & Not an RCT. \\
\hline Fryklund 1991 & Not related to replacement of long-term catheters. \\
\hline Hayward 2012 & Not related to replacement of long-term catheters. \\
\hline Lee 2015 & Intervention not relevant. \\
\hline Li 2014 & Not related to replacement of long-term catheters. \\
\hline Moore 2004 & Intervention not relevant. The study is about washouts. \\
\hline Nalinthip 1996 & Study is on intermittent, not long-term catheters. \\
\hline NCT01785966, 2013 & Does not address long-term catheter replacement. \\
\hline NCT01797146, 2013 & Short term catheters. \\
\hline NCT02196987, 2014 & Participants do not have long-term catheters. \\
\hline Norton 1987 & Does not address catheter replacement. \\
\hline Oberst 1981 & Participants' indwelling catheters are post-operative and not long-term. \\
\hline Obolensky 1975 & Participants have short-term catheters. \\
\hline Pickard 1996 & Study only deals with new catheter insertion and not replacement. \\
\hline Platt 1983 & Particpants' catheters are not long-term and replacement of catheter is not investigated. \\
\hline Raz 2000 & Studies policies for replacing long-term catheter for UTI, not routine replacement. \\
\hline Reid 1982 & Not an RCT. \\
\hline Samimi 2010 & Deals with bladder washouts and does not address replacement of catheters. \\
\hline Savage 1982 & Does not address catheter replacement. \\
\hline Schneeberger 1992 & Only addresses catheter removal. \\
\hline Shimpuku 2013 & Catheters in these subjects are not long-term. \\
\hline Siderias 2004 & Participants catheters' are not long-term. \\
\hline Sperling 2014 & Participants have suprapubic catheters. \\
\hline Sweet 1985 & Intervention not related to replacement of catheter. \\
\hline Taweesangsuksalul 2005 & Intermittent catheters. \\
\hline Webster 2000 & Participants' catheters are only temporary. \\
\hline
\end{tabular}




\begin{tabular}{ll}
\hline Study & Reason for exclusion \\
\hline Webster 2006 & Patients with long term-catheters were excluded from this study. \\
\hline Wilde 2011 & Replacement of long-term catheter not studied. \\
\hline Wilde 2015 & Intervention not relevant. \\
\hline Williamson 1982 & Catheters in these subjects are not long-term. \\
\hline Zhao 1994 & \\
\hline
\end{tabular}

\section{DATA AND ANALYSES}

Comparison 1. Monthly \& PRN (as needed) catheter replacement versus PRN (as needed) catheter replacement

\begin{tabular}{|c|c|c|c|c|}
\hline Outcome or subgroup title & No. of studies & $\begin{array}{l}\text { No. of partici- } \\
\text { pants }\end{array}$ & Statistical method & Effect size \\
\hline $\begin{array}{l}1 \text { Symptomatic CAUTI (up to } 6 \text { months af- } \\
\text { ter replacement) }\end{array}$ & 1 & & $\begin{array}{l}\text { Risk Ratio (M-H, Fixed, } \\
95 \% \mathrm{Cl})\end{array}$ & Subtotals only \\
\hline
\end{tabular}

Analysis 1.1. Comparison 1 Monthly \& PRN (as needed) catheter replacement versus PRN (as needed) catheter replacement, Outcome 1 Symptomatic CAUTI (up to 6 months after replacement).

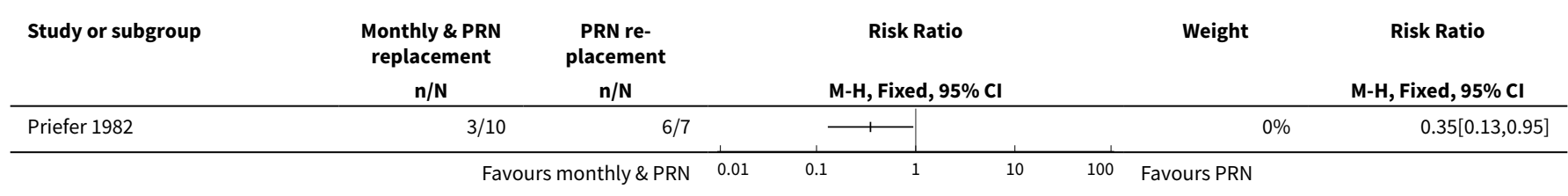

\section{Comparison 2. Antibiotics at time of replacement versus no antibiotics at time of replacement}

\begin{tabular}{|c|c|c|c|c|}
\hline Outcome or subgroup title & No. of studies & $\begin{array}{l}\text { No. of partici- } \\
\text { pants }\end{array}$ & Statistical method & Effect size \\
\hline 1 Positive urine culture & 1 & & Risk Ratio (M-H, Fixed, 95\% Cl) & Totals not selected \\
\hline $\begin{array}{l}1.13 \text { days after replace- } \\
\text { ment }\end{array}$ & 1 & & Risk Ratio (M-H, Fixed, 95\% Cl) & $0.0[0.0,0.0]$ \\
\hline $\begin{array}{l}1.27 \text { days after replace- } \\
\text { ment }\end{array}$ & 1 & & Risk Ratio (M-H, Fixed, 95\% Cl) & $0.0[0.0,0.0]$ \\
\hline $\begin{array}{l}1.314 \text { days after replace- } \\
\text { ment }\end{array}$ & 1 & & Risk Ratio (M-H, Fixed, 95\% Cl) & $0.0[0.0,0.0]$ \\
\hline
\end{tabular}




\begin{tabular}{lllll}
\hline Outcome or subgroup title & No. of studies & $\begin{array}{l}\text { No. of partici- } \\
\text { pants }\end{array}$ & Statistical method & Effect size \\
\hline $\begin{array}{l}1.4 \text { 28 days after replace- } \\
\text { ment }\end{array}$ & 1 & Risk Ratio (M-H, Fixed, 95\% Cl) & $0.0[0.0,0.0]$ \\
\hline 2 Infection & 1 & Risk Ratio (M-H, Fixed, 95\% Cl) & Subtotals only \\
\hline 3 Bacteraemia & 1 & Risk Ratio (M-H, Fixed, 95\% Cl) & $0.0[0.0,0.0]$ \\
\hline 4 Death & 1 & Risk Ratio (M-H, Fixed, 95\% Cl) & Subtotals only \\
\hline
\end{tabular}

Analysis 2.1. Comparison 2 Antibiotics at time of replacement versus no antibiotics at time of replacement, Outcome 1 Positive urine culture.

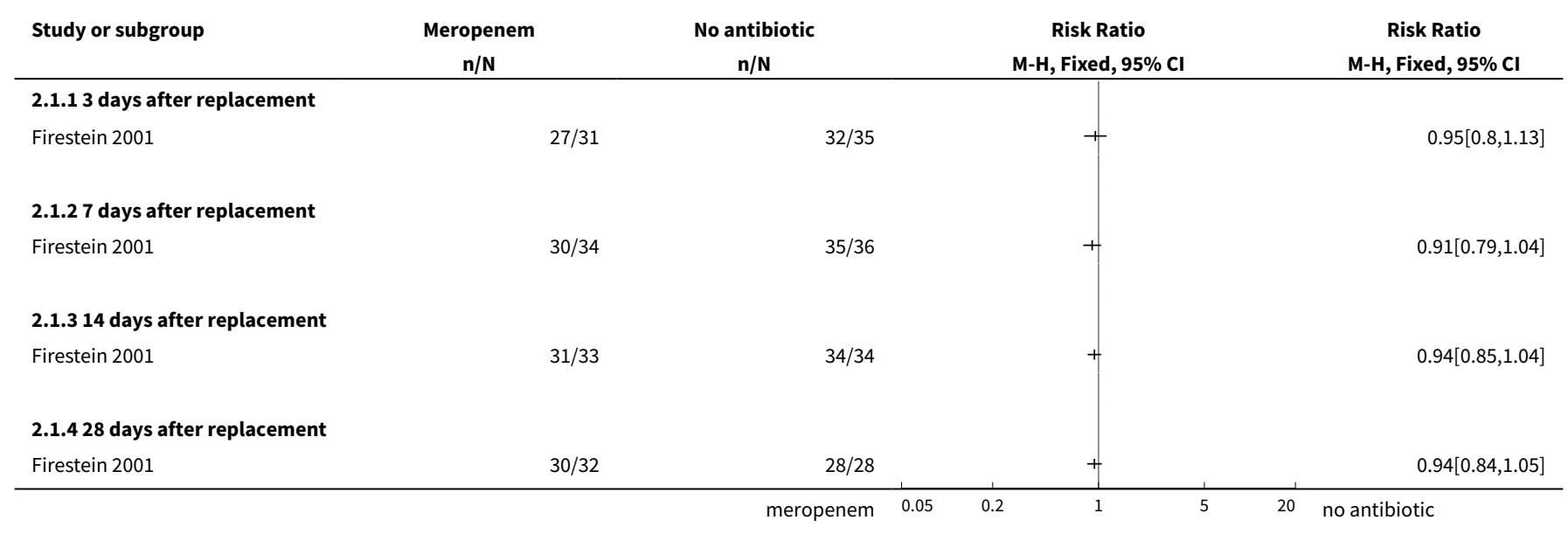

Analysis 2.2. Comparison 2 Antibiotics at time of replacement versus no antibiotics at time of replacement, Outcome 2 Infection.

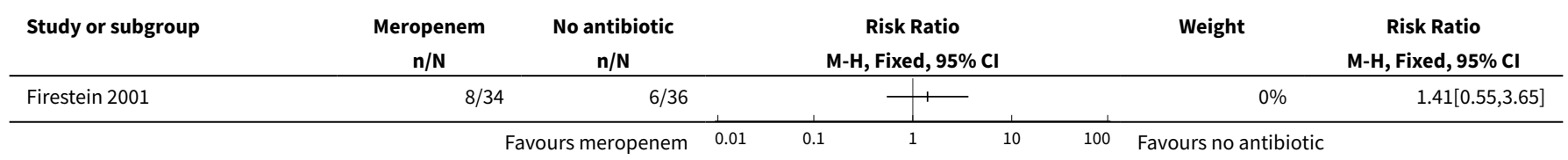

Analysis 2.3. Comparison 2 Antibiotics at time of replacement versus no antibiotics at time of replacement, Outcome 3 Bacteraemia.

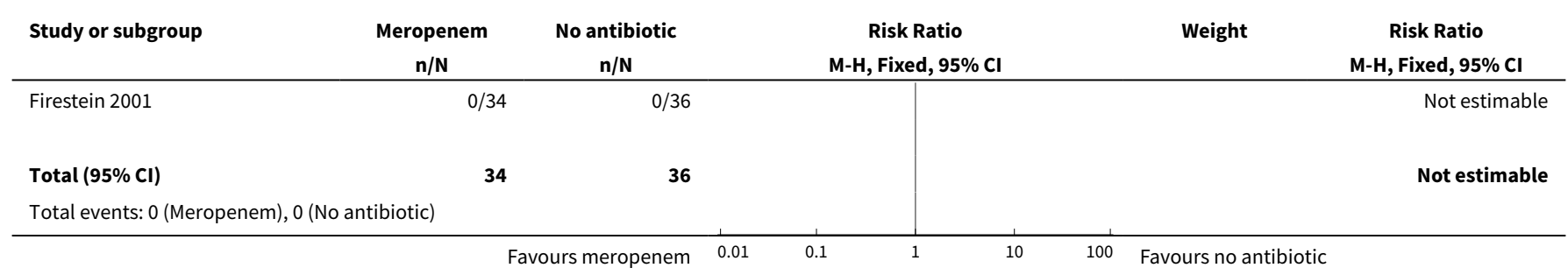




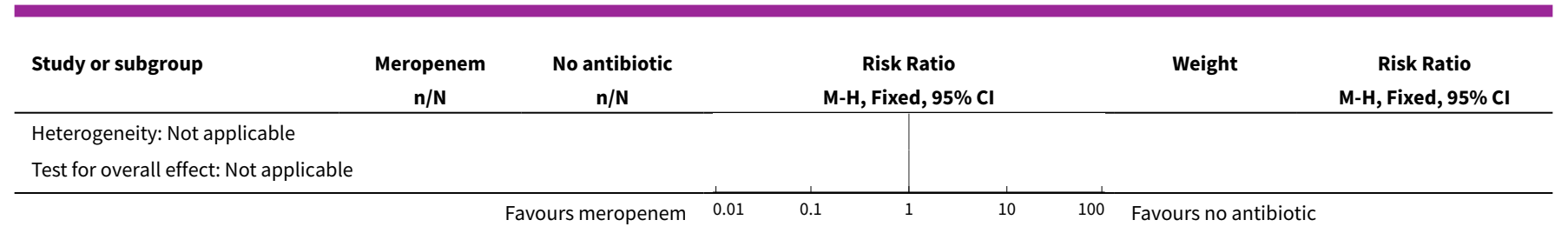

Analysis 2.4. Comparison 2 Antibiotics at time of replacement versus no antibiotics at time of replacement, Outcome 4 Death.

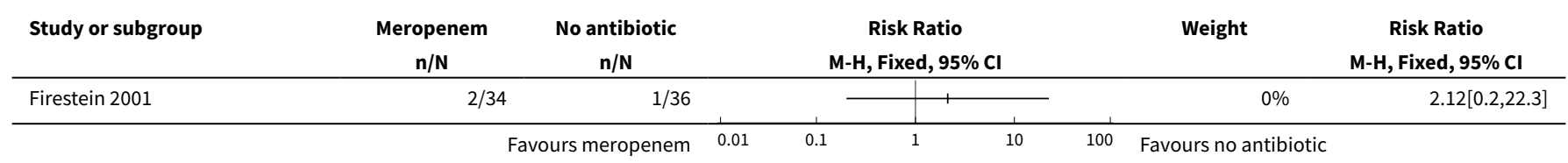

Comparison 3. Sterile water versus $0.05 \%$ chlorohexidine gluconate for periurethral cleansing during replacement

\begin{tabular}{|c|c|c|c|c|}
\hline Outcome or subgroup title & No. of studies & $\begin{array}{l}\text { No. of partici- } \\
\text { pants }\end{array}$ & Statistical method & Effect size \\
\hline $\begin{array}{l}1 \text { Symptomatic CAUTI (up to } 14 \text { days } \\
\text { after repacement) }\end{array}$ & 1 & 16 & $\begin{array}{l}\text { Risk Ratio (M-H, Fixed, 95\% } \\
\text { Cl) }\end{array}$ & $0.0[0.0,0.0]$ \\
\hline $\begin{array}{l}2 \text { Asymptomatic bacteruria (as defined } \\
\text { by positive urine culture) }\end{array}$ & 1 & & $\begin{array}{l}\text { Risk Ratio (M-H, Fixed, 95\% } \\
\mathrm{Cl} \text { ) }\end{array}$ & $\begin{array}{l}\text { Totals not select- } \\
\text { ed }\end{array}$ \\
\hline 2.10 day after replacement & 1 & & $\begin{array}{l}\text { Risk Ratio (M-H, Fixed, 95\% } \\
\mathrm{Cl})\end{array}$ & $0.0[0.0,0.0]$ \\
\hline 2.27 days after replacement & 1 & & $\begin{array}{l}\text { Risk Ratio (M-H, Fixed, 95\% } \\
\mathrm{Cl})\end{array}$ & $0.0[0.0,0.0]$ \\
\hline 2.314 days after replacement & 1 & & $\begin{array}{l}\text { Risk Ratio (M-H, Fixed, 95\% } \\
\mathrm{Cl})\end{array}$ & $0.0[0.0,0.0]$ \\
\hline
\end{tabular}

Analysis 3.1. Comparison 3 Sterile water versus $0.05 \%$ chlorohexidine gluconate for periurethral cleansing during replacement, Outcome 1 Symptomatic CAUTI (up to 14 days after repacement).

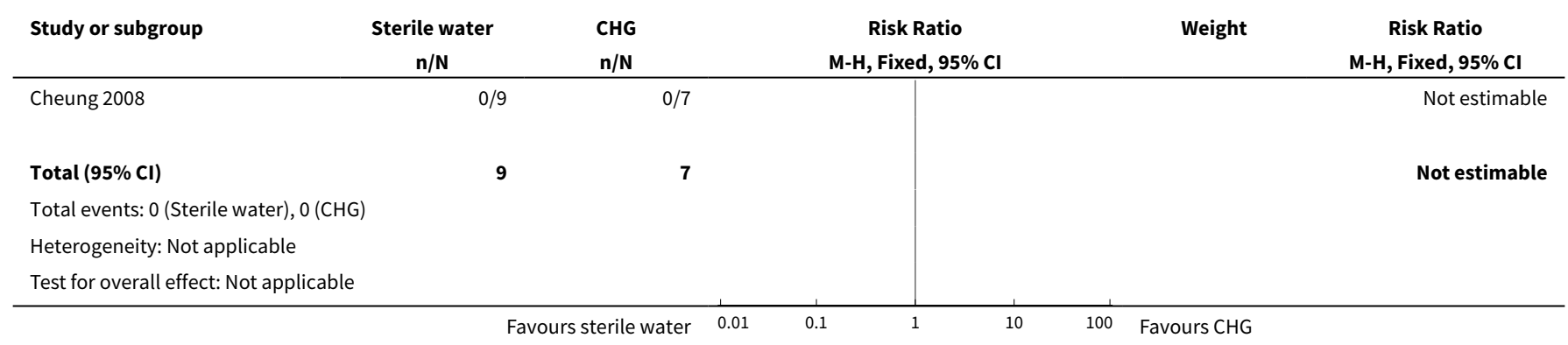


Analysis 3.2. Comparison 3 Sterile water versus $0.05 \%$ chlorohexidine gluconate for periurethral cleansing during replacement, Outcome 2 Asymptomatic bacteruria (as defined by positive urine culture).

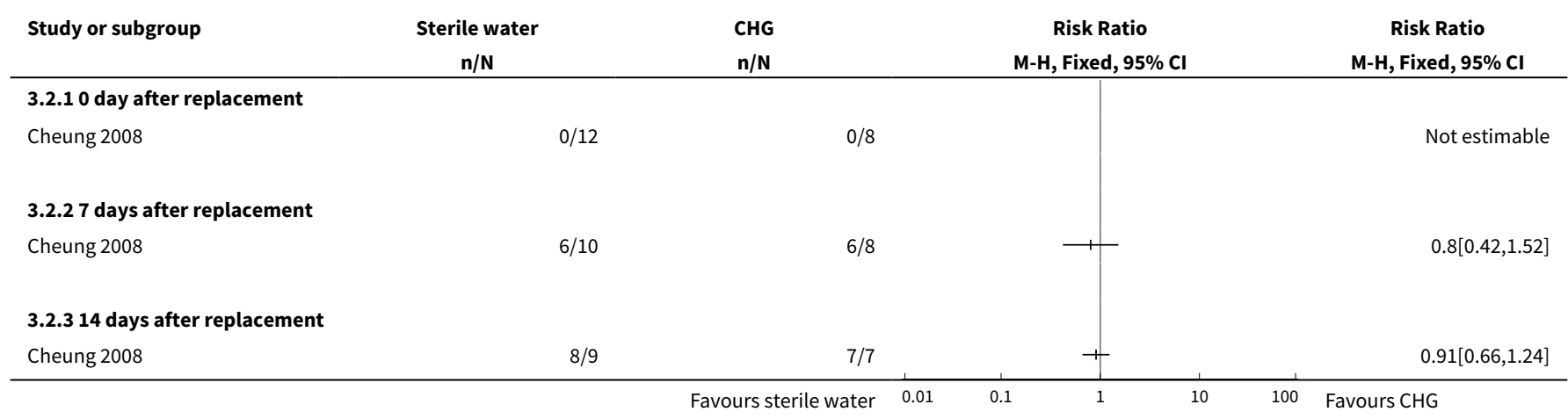

\section{APPENDICES}

\section{Appendix 1. Cochrane Incontinence Group Specialised Register search strategy}

The terms used to search the Incontinence Group Specialised Register are given below:

( (\{DESIGN.CCT*\} OR \{DESIGN.RCT*\}) AND \{INTVENT.MECH.CATH* $\})$

(All searches were of the keyword field of Reference Manager 2012).

\section{CONTRIBUTIONS OF AUTHORS}

Fergus PM Cooper (FC), Cameron Edwin Alexander (CEA), Sanjay Sinha (SS), and Muhammad Imran Omar (MIO) were responsible for the conception of the protocol. FC, CEA and SS were responsible for abstract screening. All review authors performed full-text screening, data extraction and analysis. FC and MIO assessed the quality of evidence. MIO also provided methodological expertise. FC took lead in drafting the first version of the review. All review authors contributed in writing the final manuscript.

\section{DECLARATIONS OF INTEREST}

Fergus PM Cooper: None known

Cameron Edwin Alexander: None known

Sanjay Sinha was on the Advisory Board for Ranbaxy. The extent of the relationship is very limited both in terms of any monetary compensation as well as in terms of time or responsibility. As such, it does not constitute a conflict of interest for the proposed project.

Muhammad Imran Omar: None known

\section{SOURCES OF SUPPORT}

\section{Internal sources}

- No sources of support supplied

\section{External sources}

- The National Institute for Health Research (NIHR), UK.

This project was supported by the National Institute for Health Research, via Cochrane Infrastructure, Cochrane Programme Grant or Cochrane Incentive funding to the Incontinence Group. The views and opinions expressed therein are those of the authors and do not necessarily reflect those of the Systematic Reviews Programme, NIHR, NHS or the Department of Health. 


\section{DIFFERENCES BETWEEN PROTOCOL AND REVIEW}

We used "urinary tract infection" as one of the primary outcomes while writing the protocol. However, we realised symptomatic catheter-associated urinary tract infection (CAUTI) is clinically more relevant and important. Therefore, primary outcome was changed to "symptomatic catheter-associated urinary tract infection (CAUTI) as defined by trialists".

The searches of ClinicalTrials.gov and WHO ICTRP are now fully incorporated into the search for the Cochrane Incontinence Specialised Register and were therefore not run separately.

\section{INDEX TERMS}

\section{Medical Subject Headings (MeSH)}

${ }^{\star}$ Catheters, Indwelling; *Urinary Catheters; Age Factors; Anti-Infective Agents, Local; Antibiotic Prophylaxis; Chlorhexidine; Decision Making; Device Removal [methods] [ ${ }^{\star}$ standards]; Health Policy; Pharmaceutical Solutions; Randomized Controlled Trials as Topic; Sex Factors; Time Factors; Urinary Catheterization [methods] [ ${ }^{*}$ standards]; Urinary Tract Infections [ ${ }^{*}$ prevention \& control]

\section{MeSH check words}

Aged; Female; Humans; Male 